\title{
Transactions
}

Cite this: Dalton Trans., 2011, 40, 1419

wWW.rsc.org/dalton

PERSPECTIVE

\section{Vanadium and molybdenum peroxides: synthesis and catalytic activity in oxidation reactions}

\author{
Valeria Conte* and Barbara Floris \\ Received 22nd June 2010, Accepted 22nd October 2010 \\ DOI: 10.1039/c0dt00706d
}

Catalysis by transition metal ions in oxidation reactions with hydrogen peroxide and alkyl

hydroperoxides is a leading topic in the pursuit of more sustainable and selective processes, to obtain compounds with high added value. The most recent achievements concerning the synthesis and characterization, as well as the key aspects of reactivity, of $\mathrm{V}(\mathrm{v})$ and $\mathrm{Mo}(\mathrm{VI})$ peroxo complexes have been collected here.

\section{Introduction}

The oxidative functionalization of organic and inorganic substrates is frequently obtained with peroxides, in mild conditions, in high yields and remarkable selectivity. ${ }^{1-3}$ Originally, organic peracids, hydrogen peroxide and alkyl hydroperoxides were tested; however, it resulted that only with peracids were synthetically interesting procedures available because of their much higher

Università di Roma Tor Vergata, Dipartimento di Scienze e Tecnologie Chimiche, Via della Ricerca Scientifica, 00133, Roma, Italy. E-mail: valeria. conte@uniroma2.it,floris@uniroma2.it; Fax: (+) 3906 72594328; Tel: (+) 390672594014 reactivity in comparison with that of $\mathrm{H}_{2} \mathrm{O}_{2}, t$-butyl hydroperoxide or other simple peroxidic species. ${ }^{2,3}$

Notably, from the applied point of view, hydrogen peroxide is the most interesting one in consideration of its high oxygen content as well as its sustainability. ${ }^{4}$ Unfortunately, being a weak oxidant, in order to be truly attractive, it needs to be activated. To this aim, the most effective catalysts, not considering strong bases or Brønsted acids, are some of the transition metal ions, above all those from groups 4-7, i.e. Ti, V, Cr, Mo, W and Re, in their highest oxidation states. The discovery of the catalytic activity of some of these metals in oxidation reactions with $\mathrm{H}_{2} \mathrm{O}_{2}$ was made early in the first half of the last century. ${ }^{5}$ Later, it was demonstrated ${ }^{6}$ that

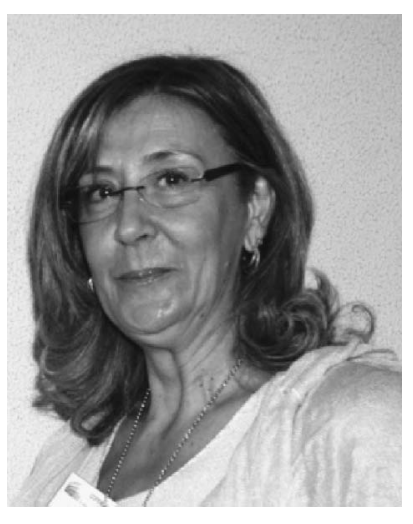

Valeria Conte
Laurea (1982) and PhD (1986) in Chemistry at Padova University. 85-86 Ph.D. student with prof. J.K. Stille at Colorado State University. 86-87 Consultant for INTEROX chimica, 8788 CNR fellowship and 88-98 CNR Researcher at "CMRO" Padova University. 93 "NATOCNR Senior Fellowship at Colorado Stato University. 98-01 Associate professor of Organic Chemistry, University of Foggia. From 2001, Associate Professor and then Full professor in Organic Chemistry at University of Roma "Tor Vergata". Coordinator of COST projects in D12, D29 and D40 Actions. Italian Representative in D24 and D40 COST actions. Member of Italian and American Chemical Societies. Member of international advisory boards of "ADHOC International Symposium on Dioxygen Activation and Homogeneous Catalytic Oxidation" and "International Symposium on Chemistry and Biochemistry of Vanadium".

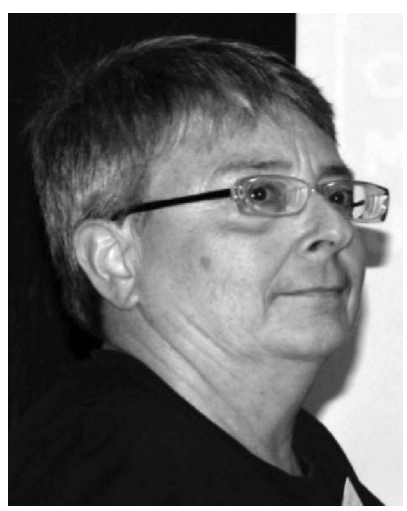

Barbara Floris
After graduating in Chemistry in 1969, Barbara Floris became Assistant Professor in 1971, Associate Professor in 1983 and Full Professor in 1994, working at the Universities of Roma "La Sapienza” (1971-1988), Napoli "Federico II" (1994-95), and Roma "Tor Vergata” (19891994 and from 1996 to date). She spent periods of research in USA, as Visiting Professor or as Visiting Researcher (Auburn University, Virginia Commonwealth University, Texas A\&M University). She was also invited as Visiting Professor at the University of Katowice (Poland) and at the Comoenius University of Bratislava (then Czechoslovakia). Member of Italian Chemical Society and American Chemical Society. 
similar reactivity is observed also when alkyl hydroperoxides are used as the primary oxidants.

An extraordinary step forward in this field was obtained by Katsuki and Sharpless ${ }^{7}$ in 1980 (in 2001 such a discovery was credited with the Nobel Prize), when the titanium catalysed enantioselective oxidation of prochiral allylic alcohols with alkyl hydroperoxides was realized, in the presence of chiral non racemic tartrates.

Studies in this field have been dedicated both to the applicability of such species as oxidants of numerous substrates, as well as to the elucidation of the mechanistic details of the oxidative process. The catalytic effect of the metal ions can be described in a very simple way as indicated in Scheme 1. The nature of the real oxidant depends on the peroxide used and on its interaction with the metal precursor, high-valent peroxometal species usually being the active intermediates. ${ }^{3,8}$

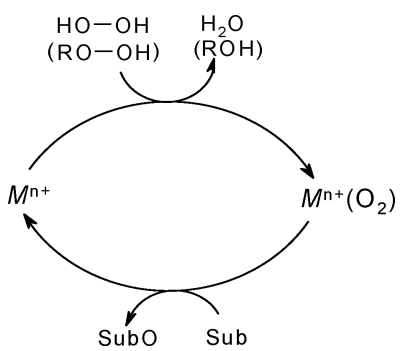

Scheme 1 Metal catalysed oxidations with peroxide.

As already anticipated, the reactivity of the peroxo $\dagger$ and/or peroxide metal complexes is orders of magnitude higher than that of the peroxidic precursor, either $\mathrm{H}_{2} \mathrm{O}_{2}$ or $\mathrm{ROOH}$.

The elucidation of the essential steps in the metal catalyzed oxidations with peroxides, directed research interests towards the understanding of the structure, in solid state as well as in solution, and the chemical behaviour of peroxo metal complexes. ${ }^{1,3,8}$

As far as the structure of the active complexes (indicated in Scheme 1) is concerned, an $\eta^{2}$ triangular arrangement of the bidentate peroxo group with the metal is very frequently observed..$^{1,2,3}$

The classification of the peroxo structures was developed more than three decades ago by Vaska. ${ }^{9}$ Interestingly, all of these have been found for different metals: in Scheme 2 selected examples, representative for the diverse coordination modes, are shown. ${ }^{8,10}$

Furthermore, binding to the metal of two or more peroxidic moieties is possible, with group 6 metals up to four peroxo groups have been observed. ${ }^{11} \mathrm{~V}(\mathrm{v})$ poly-peroxo complexes have been characterized both in solution and in the solid state ${ }^{12-14}$ and for some of these the oxidative chemistry has been elucidated. ${ }^{15}$

Bimetallic as well as tetranuclear $\mu$-peroxo derivatives, with an $\mathrm{O}_{2}{ }^{2-}$ ligand bridging the metals in a variety of coordination modes, have been described. ${ }^{1}$

During the years, a number of books, chapters and reviews have been offered to researchers, bringing together the major structural and oxidative features of metal peroxides. ${ }^{1-3,8,16-19}$

$\dagger$ Albeit being aware of the recent IUPAC suggestions to use peroxido to indicate the presence of the $\mathrm{O}_{2}{ }^{2-}$ group, throughout the paper we use the peroxo nomenclature in consideration of its large diffusion even in the most recent literature.
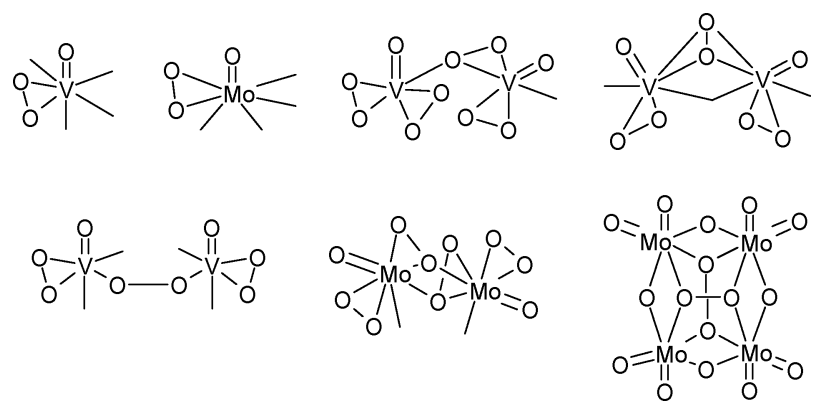

Scheme 2 Examples of the coordination modes for peroxo and $\mu$-peroxo complexes.

In this review we concentrate on the recent achievements obtained in this field, while for less up-to-date literature interested readers are referred to relevant books. ${ }^{1,20}$ With respect to the structural features of isolated peroxo species, an accurate collection of data has been published recently by Sergienko, both for vanadium ${ }^{21}$ and molybdenum..$^{22}$

The present review will not deal with the bio-related aspects of the chemistry of peroxo species, or with the rich literature related to polyoxometallates species, which in several cases, in catalytic processes, are the precursors of peroxidic active oxidants.

\section{Synthesis and structural aspects}

Peroxo complexes of the $\mathrm{d}^{0}$ metals are typically prepared by reacting an aqueous solution of hydrogen peroxide with a metal precursor. The peroxidic species thus formed in solution can be isolated upon the addition of appropriate ligands. This quite old $^{23,24}$ but simple procedure is indeed general and is still applied with different metals and ligands. Almost all of the peroxo species collected in the following, Schemes 3 and 9 and in Tables 1, 2 and 3, have been prepared in such a mode. The order of addition of the peroxide and the ligand may vary and sometimes a ligand containing an oxo species is initially prepared and subsequently reacted with $\mathrm{H}_{2} \mathrm{O}_{2}$. For the vanadium derivatives, the most often used precursors are $\mathrm{NH}_{4} \mathrm{VO}_{3}$ or $\mathrm{V}_{2} \mathrm{O}_{5}$. In some instances, derivatives with vanadium in a lower oxidation state, such as vanadyl sulfate, are also utilized.

In the case of the molybdenum derivatives, which are likely the most numerous and best characterized species, ${ }^{8}$ a very similar procedure applies. Typically, with $\mathrm{Mo}(\mathrm{VI})$, the formation of diperoxides is highly favoured, in fact the number of isolated and characterized monoperoxo complexes is lower in comparison with the diperoxo counterpart (see also the complexes reported in Table 3). Very often, peroxo molybdenum species are prepared by directly reacting $\mathrm{MoO}_{3}$, or ammonium heptamolybdate, with an appropriate amount of hydrogen peroxide and the desired ligand, with the order of addition being somewhat flexible. Alternatively, the synthesis of the ligand containing a dioxo Mo precursor, followed by its reaction with $\mathrm{H}_{2} \mathrm{O}_{2}$ is a viable procedure that is often used.

Interestingly, a peculiar synthesis has been done for monoperoxo $\mathrm{V}$ and Mo derivatives 12 and 59. In the latter example, the Mo(IV) precursor was treated with dioxygen (Scheme 4). Such a procedure, which is rarely employed, was known for $\left[(\mathrm{CN})_{4} \mathrm{MoO}\left(\mathrm{O}_{2}\right)\right]\left[\left(\mathrm{PPh}_{4}\right)_{2}\right]$ and for some tetraphenyl and octaethyl substituted Mo porphyrins. ${ }^{25}$ 
Monoperoxo complexes
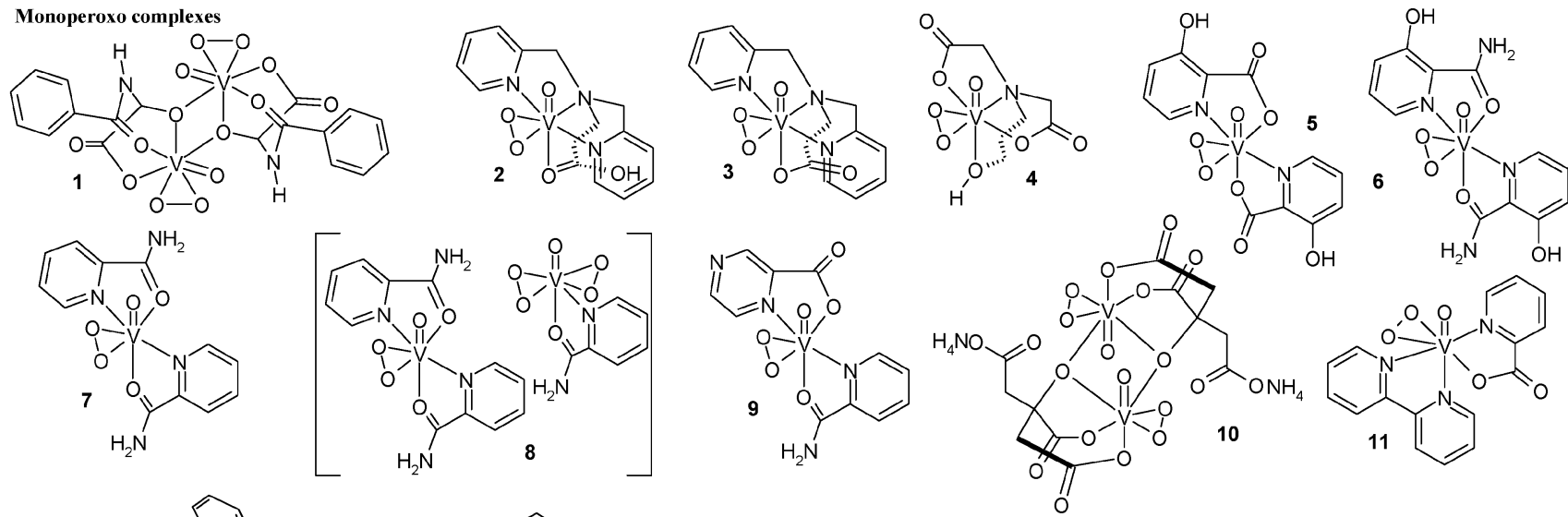

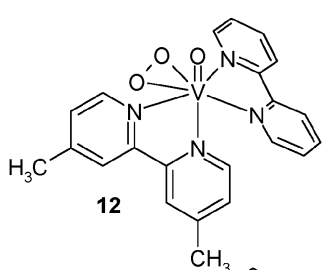

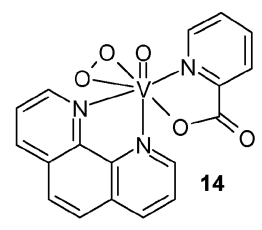<smiles></smiles>

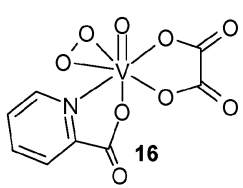

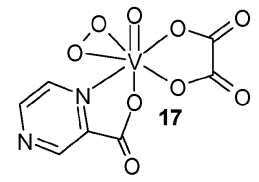<smiles>O=C1OC(Cc2ccccc2)C(=O)OC(Cc2ccccc2)C(Cc2ccccc2)(O[PH]2(=O)(O)OO2)OP2(O)(OO2)O1</smiles>

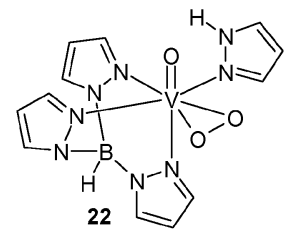

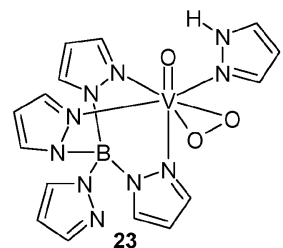<smiles></smiles>

Diperoxo Complexes

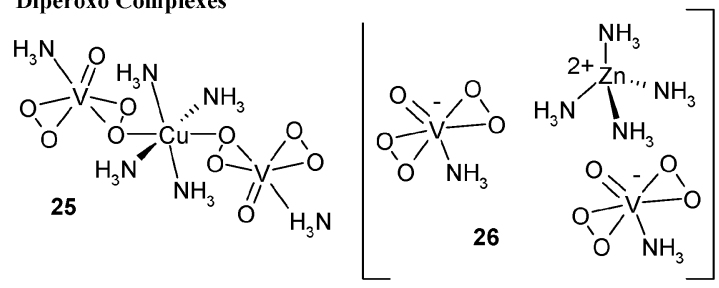<smiles>O=P1(F)OO1</smiles>

29<smiles>O=C1OC2(CO2)N1P(=O)(O)c1ccccc1-c1ccccc1</smiles>

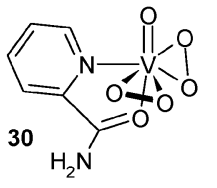<smiles></smiles><smiles>CC(C)C[C@H](N)C(=O)NCC(=O)OP12(OO1)OO2</smiles>

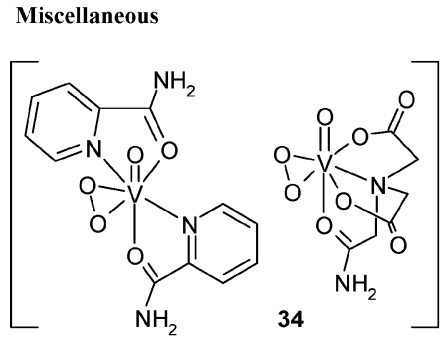

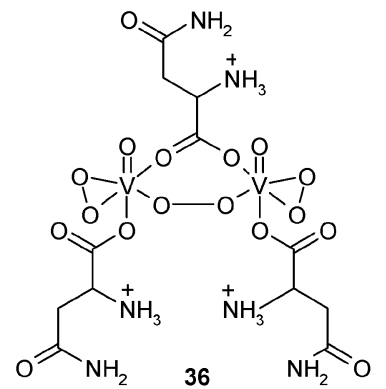

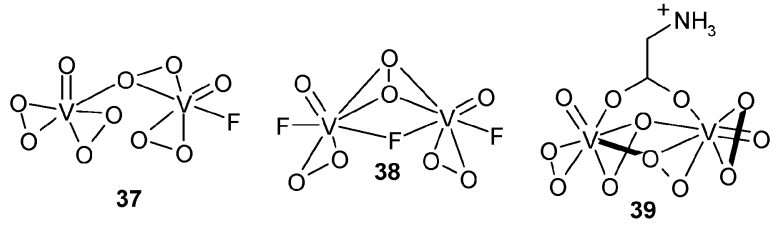

Anchored

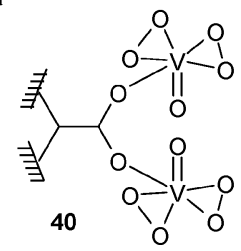<smiles>C[C@@]1(C(=O)OP23(CO2)OO3)C[C@H]2C[C@@H]21</smiles>

Scheme 3 The structure of isolated vanadium(v) peroxo complexes, numbered as in Tables 1 and 2 . The charges on the complexes are omitted for clarity. 
Table 1 Selected physicochemical properties of vanadium peroxo complexes

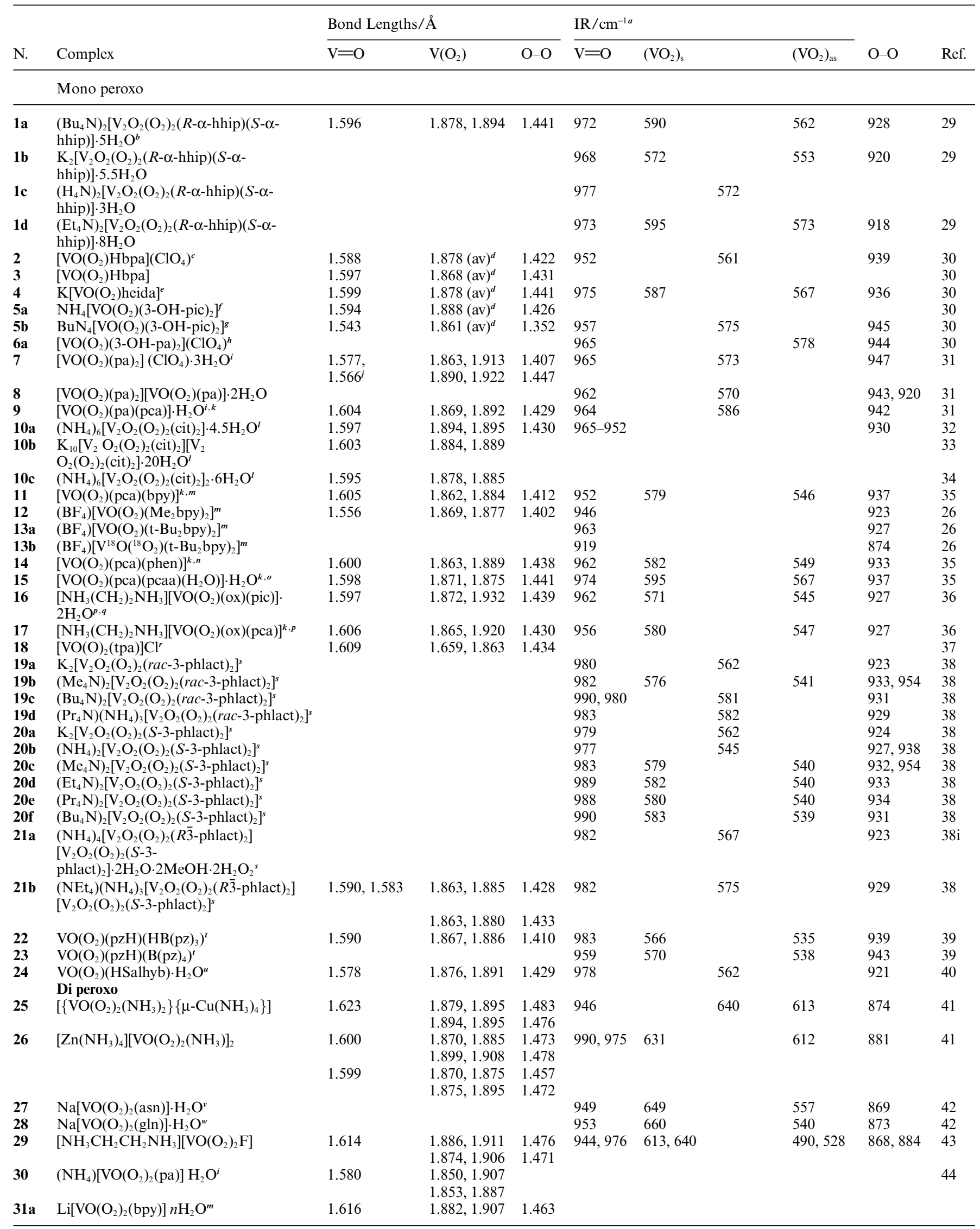




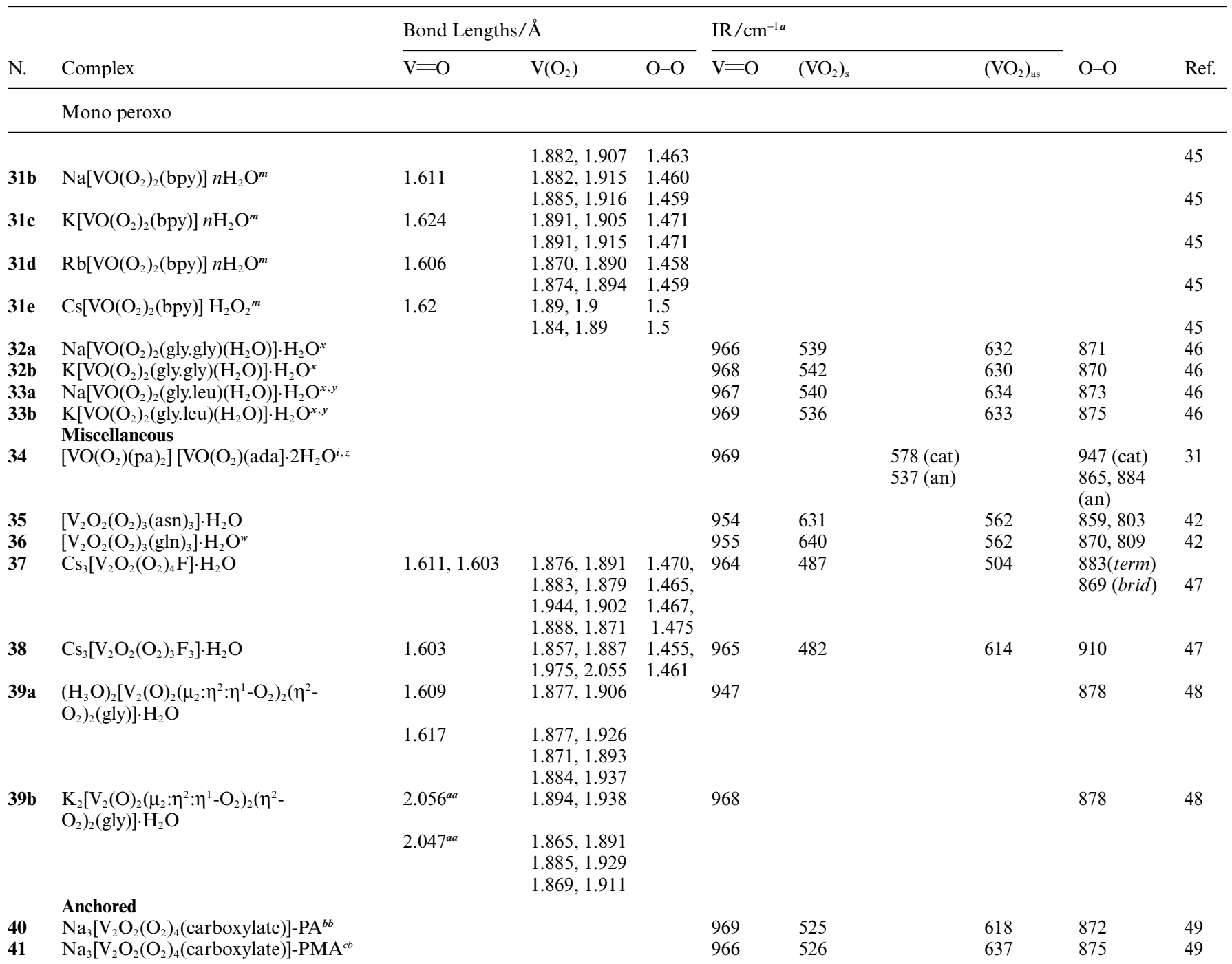

${ }^{a}$ Assignment of the symmetric and asymmetric metal-peroxo stretch, when not clearly stated by the authors, was made on the basis of reported discussion ${ }^{18}{ }^{b} \alpha$-hhip $=\alpha$-hydroxyhippuric acid ${ }^{c}{ }^{\mathrm{Hbpa}}=$ bis(picolyl)- $\beta$-alanine. ${ }^{d}$ average. ${ }^{e} \mathrm{H}_{2}$ heida $=N$ - $\left(2\right.$-hydroxyethyl)iminodiacetic acid,${ }^{f} 3 \mathrm{OH}$-pic $=$ 3-hydroxypicolinic acid. ${ }^{g}$ the similar neutral complex with $t$ - $\mathrm{BuOOH},\left[\mathrm{VO}\left(t \mathrm{BuO} \mathrm{O}_{2}\right)(3-\mathrm{OH}-\mathrm{pic})_{2}\right]$, was also prepared, but no X ray analysis nor IR data are reported. ${ }^{h}$ 3-OH-pa $=3$-hydroxypicolylamide. ${ }^{i} \mathrm{pa}=$ picolinamide. ${ }^{j}$ two different molecular structures cause disorder in solid state structure. ${ }^{k}$ Hpca $=$ 2-pyrazinecarboxylic acid. ${ }^{\prime}$ cit $=$ citrate. ${ }^{m}$ bpy $=2,2^{\prime}$-bipyridine. ${ }^{n}$ phen $=1,10$-phenanthroline. ${ }^{o}$ pcaa $=2$-pyrazinecarboxyamide. ${ }^{p} \mathrm{H}_{2}$ ox $=$ oxalic acid. ${ }^{q} \mathrm{Hpic}=$ picolinic acid. ${ }^{r}$ tpa $=$ tris(2-pyridylmethyl)amine. ${ }^{s}$ 3-phlact $\mathrm{H}_{2}=3$-phenyllactic acid. ${ }^{t} \mathrm{pzH}=$ pyrazole, $\mathrm{HB}(\mathrm{pz})_{3}=\operatorname{tris}(1 H$-pyrazol-1-yl)boron hydride. ${ }^{u} \mathrm{H}_{2}$ Salhyb $=$ Schiff base from salicylaldehyde and 4-hydroxybutanoic acid hydrazide. ${ }^{v}$ asn $=$ asparagine. ${ }^{w}$ gln $=$ glutamine. ${ }^{x}$ gly $=$ glycine. ${ }^{y}$ leu $=$ leucine. ${ }^{z}$ ada $=$ carbamoylmethyliminodiacetate. ${ }^{a}$ as suggested from a referee, this length can be better attributed to a $\mathrm{V}-\mathrm{O}$ single bond bridging to the countercation. ${ }^{b b} \mathrm{PA}=$ poly (acrylate). ${ }^{c c} \mathrm{PMA}=$ poly(methacrylate $)$.

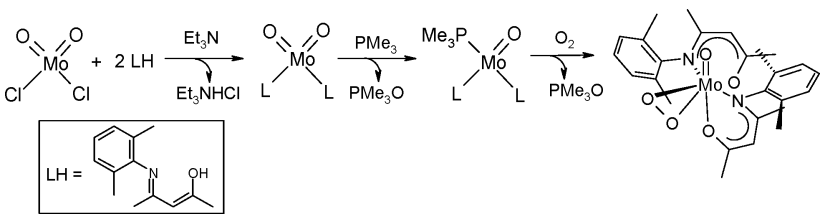

Scheme 4 The synthesis of the $\mathrm{MoO}\left(\mathrm{O}_{2}\right)(\text { ketim })_{2}$ complex 59.

Analogously, $\left(\mathrm{BF}_{4}\right)\left[\mathrm{VO}\left(\mathrm{O}_{2}\right)\left(\mathrm{Alk}_{2} \text { bpy }\right)_{2}\right]$ complexes are prepared in excellent yields starting from the corresponding $\mathrm{V}^{\mathrm{IV}} \mathrm{O}(\mathrm{OH})$ precursors and dioxygen. ${ }^{26}$ The intermediate formation of V-dioxo compounds has been demonstrated by using ${ }^{1} \mathrm{H}-\mathrm{NMR}$ and $\mathrm{UV}$-vis spectra.

\section{Peroxo vanadium complexes}

The variety of ligands used for preparing vanadium peroxo derivatives is shown in previous publication $\mathrm{s}^{1-3,13,18,21,22,27}$ and the most recent structures are collected in Scheme 3, while their salient structural and spectroscopic features are collated in Tables 1 and 2.

As to the solid state structure of vanadium peroxo compounds, the peroxide moieties can be considered in two different fashions: as an $\eta^{2}$ ligand, which occupies one coordination site, or as a chelating bidentate ligand. Without entering too much into the various geometric variants possible with both approaches, the interested readers are referred to the long discussion presented 
Table $2{ }^{51}$ V NMR chemical shifts of vanadium peroxo complexes

\begin{tabular}{|c|c|c|c|c|}
\hline N. & Compound & ${ }^{51} \mathrm{~V} \mathrm{NMR/ppm}$ & Solvent & Ref. \\
\hline & \multicolumn{4}{|l|}{ Mono peroxo } \\
\hline 42 & $\mathrm{VO}\left(\mathrm{O}_{2}\right)^{+}$ & -595 & $\mathrm{H}_{2} \mathrm{O} \mathrm{pH} \cong 7.5$ & 50 \\
\hline 43 & $\mathrm{VO}\left(\mathrm{O}_{2}\right)(\mathrm{tf})^{+a}$ & -594 & $\mathrm{H}_{2} \mathrm{O} \mathrm{pH} \cong 7.5$ & 50 \\
\hline 44 & $\mathrm{VO}\left(\mathrm{O}_{2}\right)(\mathrm{pp})^{+b}$ & -605 & $\mathrm{H}_{2} \mathrm{O} \mathrm{pH} \cong 7.5$ & 50 \\
\hline 45 & $\mathrm{VO}\left(\mathrm{O}_{2}\right)(\mathrm{V}-\mathrm{BrPO})^{+c}$ & -1155 & $\mathrm{H}_{2} \mathrm{O} \mathrm{pH} \cong 7.5$ & 50 \\
\hline 1 & {$\left[\mathrm{~V}_{2} \mathrm{O}_{2}\left(\mathrm{O}_{2}\right)_{2}(R \text { - } \alpha \text {-hhip })(S \text { - } \alpha \text {-hhip })\right]^{2-d}$} & -576 & $\mathrm{H}_{2} \mathrm{O}$ & 29 \\
\hline 2 & {$\left[\mathrm{VO}\left(\mathrm{O}_{2}\right) \mathrm{Hbpa}\right]\left(\mathrm{ClO}_{4}\right)^{e}$} & $-624-610$ & $\mathrm{H}_{2} \mathrm{O} / \mathrm{D}_{2} \mathrm{O} \mathrm{D}{ }_{2} \mathrm{O} / \mathrm{EtOH}$ & 30 \\
\hline 46 & {$\left[\mathrm{VO}\left(\mathrm{O}_{2}\right)(\mathrm{bpg})\right]^{f}$} & $-596-583$ & $\mathrm{H}_{2} \mathrm{O} / \mathrm{D}_{2} \mathrm{O} \mathrm{D} \mathrm{D}_{2} \mathrm{O} / \mathrm{EtOH}$ & 30 \\
\hline 4 & $\mathrm{~K}\left[\mathrm{VO}\left(\mathrm{O}_{2}\right)\right.$ heida $^{g}$ & -569 & $\mathrm{H}_{2} \mathrm{O}$ & 30 \\
\hline $5 \mathbf{b}$ & $\mathrm{BuN}_{4}\left[\mathrm{VO}\left(\mathrm{O}_{2}\right)(3-\mathrm{OH}-\mathrm{pic})_{2}\right]^{h}$ & $-597(-575,-626)^{i}$ & $\mathrm{H}_{2} \mathrm{O}$ & 30 \\
\hline $5 c$ & $\mathrm{~K}\left[\mathrm{VO}\left(\mathrm{O}_{2}\right)(3-\mathrm{OH}-\mathrm{pic})_{2}\right]^{h}$ & $-575(-597,-626)^{i}$ & $\mathrm{H}_{2} \mathrm{O}$ & 30 \\
\hline 47 & {$\left[\mathrm{VO}\left(t \mathrm{BuO}_{2}\right)(3-\mathrm{OH}-\mathrm{pic})_{2}\right]^{h}$} & $-591,-620^{j}$ & $\mathrm{H}_{2} \mathrm{O}$ & 30 \\
\hline 48 & {$\left[\mathrm{VO}\left(t \mathrm{BuO}_{2}\right)(3-\mathrm{OH}-\mathrm{pa})_{2}\right]^{2+k}$} & -589 & $\mathrm{H}_{2} \mathrm{O}$ & 30 \\
\hline 6a & {$\left[\mathrm{VO}\left(\mathrm{O}_{2}\right)(3-\mathrm{OH}-\mathrm{pa})_{2}\right]\left(\mathrm{ClO}_{4}\right)^{k}$} & $-590-613^{l}$ & $\mathrm{H}_{2} \mathrm{O}$ & 30 \\
\hline 6b & {$\left[\mathrm{VO}\left(\mathrm{O}_{2}\right)(3-\mathrm{OH}-\mathrm{pa})_{2}\right] \mathrm{Cl}^{k}$} & $-590-611^{m}$ & $\mathrm{H}_{2} \mathrm{O}$ & 30 \\
\hline 7 & {$\left[\mathrm{VO}\left(\mathrm{O}_{2}\right)(\mathrm{pa})_{2}\right]^{+n}$} & -603 & $\mathrm{H}_{2} \mathrm{O}, \mathrm{pH} 0-3.6$ & 31 \\
\hline 11 & {$\left[\mathrm{VO}\left(\mathrm{O}_{2}\right)(\mathrm{pca})(\mathrm{bpy})\right]^{o, p}$} & -560 & $\mathrm{CH}_{2} \mathrm{Cl}_{2}$ & 35 \\
\hline 14 & {$\left[\mathrm{VO}\left(\mathrm{O}_{2}\right)(\mathrm{pca})(\mathrm{phen})\right]^{o, q}$} & -562 & $\mathrm{CH}_{2} \mathrm{Cl}_{2}$ & 35 \\
\hline 15 & {$\left[\mathrm{VO}\left(\mathrm{O}_{2}\right)(\mathrm{pca})(\mathrm{pcaa})\left(\mathrm{H}_{2} \mathrm{O}\right)\right] \cdot \mathrm{H}_{2} \mathrm{O}^{o, r}$} & br, -520 to -545 & $\mathrm{H}_{2} \mathrm{O}, \mathrm{pH} 3.75$ & 35 \\
\hline 16 & {$\left[\mathrm{VO}\left(\mathrm{O}_{2}\right)(\mathrm{ox})(\mathrm{pic})\right]^{2-s, t}$} & -604 & $\mathrm{H}_{2} \mathrm{O}$ & 36 \\
\hline 17 & {$\left[\mathrm{VO}\left(\mathrm{O}_{2}\right)(\mathrm{ox})(\mathrm{pca})\right]^{2-o, t}$} & -629 & $\mathrm{H}_{2} \mathrm{O}$ & 36 \\
\hline 18 & {$\left[\mathrm{~V}_{2} \mathrm{O}_{2}\left(\mathrm{O}_{2}\right)_{2}(\text { rac-3-phlact })_{2}\right]^{2-u}$} & -604 & $\mathrm{H}_{2} \mathrm{O}$ & 38 \\
\hline 24 & $\mathrm{VO}\left(\mathrm{O}_{2}\right)(\mathrm{HSalhyb}) \cdot \mathrm{H}_{2} \mathrm{O}^{v}$ & -551 & $\mathrm{CD}_{3} \mathrm{OD}$ & 40 \\
\hline 22 & $\mathrm{VO}\left(\mathrm{O}_{2}\right)(\mathrm{pzH})\left(\mathrm{HB}(\mathrm{pz})_{3}\right)^{w}$ & -623 & $\mathrm{CDCl}_{3}$ & 39 \\
\hline 23 & $\mathrm{VO}\left(\mathrm{O}_{2}\right)(\mathrm{pzH})\left(\mathrm{B}(\mathrm{pz})_{4}\right)^{w}$ & $-625,-707$ & $\mathrm{CDCl}_{3}$ & 39 \\
\hline 49 & {$\left[\mathrm{VO}\left(\mathrm{O}_{2}\right)(\mathrm{ma})_{2}\right]^{-x}$} & -563.6 & $\mathrm{H}_{2} \mathrm{O}(\mathrm{NaCl})$ & 51,52 \\
\hline \multirow[t]{2}{*}{50} & {$\left[\mathrm{VO}\left(\mathrm{O}_{2}\right)(\mathrm{ur})\right]^{2-y}$} & -610 & $\mathrm{H}_{2} \mathrm{O}(\mathrm{NaCl})$ & 51,52 \\
\hline & Di peroxo & & & \\
\hline 51 & {$\left[\mathrm{VO}\left(\mathrm{O}_{2}\right)_{2} \mathrm{Ox}\right]^{3-t}$} & -738 & $\mathrm{D}_{2} \mathrm{O}$ & 53 \\
\hline 52 & {$\left[\mathrm{VO}\left(\mathrm{O}_{2}\right)_{2}(\mathrm{pp})\right]^{-b}$} & -700 & $\mathrm{H}_{2} \mathrm{O}$ & 50 \\
\hline 29 & {$\left[\mathrm{VO}\left(\mathrm{O}_{2}\right)_{2} \mathrm{~F}\right]^{2-}$} & $-714, \mathrm{~d}\left(\mathrm{~J}_{\mathrm{VF}}=163 \mathrm{~Hz}\right),-689$ & $\mathrm{H}_{2} \mathrm{O}$ & 43,47 \\
\hline 53 & {$\left[\mathrm{VO}\left(\mathrm{O}_{2}\right)_{2}\left(\mathrm{H}_{2} \mathrm{O}\right)\right]^{-}$} & -700 & $\mathrm{H}_{2} \mathrm{O}$ & 43 \\
\hline 54 & {$\left[\mathrm{~V}_{2} \mathrm{O}_{2}\left(\mathrm{O}_{2}\right)_{4}(\mathrm{OH})\right]^{3-}$} & -760 & $\mathrm{H}_{2} \mathrm{O}$ & 43 \\
\hline 55 & {$\left[\mathrm{VO}\left(\mathrm{O}_{2}\right)_{2}(\mathrm{pa})\right]^{-n}$} & -732 & $\mathrm{H}_{2} \mathrm{O} / \mathrm{D}_{2} \mathrm{O}$ & 44 \\
\hline 56 & {$\left[\mathrm{VO}\left(\mathrm{O}_{2}\right)_{2}(\mathrm{Ma})\right]^{2-x}$} & -735 & $\mathrm{H}_{2} \mathrm{O}(\mathrm{NaCl})$ & 51,52 \\
\hline 57 & {$\left[\mathrm{VO}\left(\mathrm{O}_{2}\right)_{2}(\mathrm{Ur})\right]^{2-y}$} & -740 & $\mathrm{H}_{2} \mathrm{O}(\mathrm{NaCl})$ & 51,52 \\
\hline 27 & {$\left[\mathrm{VO}\left(\mathrm{O}_{2}\right)_{2}(\mathrm{asn})\right]^{-z}$} & -695 & $\mathrm{H}_{2} \mathrm{O}$ & 42 \\
\hline 28 & {$\left[\mathrm{VO}\left(\mathrm{O}_{2}\right)_{2}(\mathrm{gln})\right]^{-a a}$} & -695 & $\mathrm{H}_{2} \mathrm{O}$ & 42 \\
\hline 58 & $\begin{array}{l}\left.\left[\mathrm{VO}\left(\mathrm{O}_{2}\right)_{2} \text { (oxazole }\right)\right]^{-} \\
\text {miscellaneous }\end{array}$ & -726 & $\mathrm{H}_{2} \mathrm{O} / \mathrm{D}_{2} \mathrm{O}$ & 54 \\
\hline 35 & $\mathrm{~V}_{2} \mathrm{O}_{2}\left(\mathrm{O}_{2}\right)_{3}(\mathrm{asn})_{3}{ }^{z}$ & -694 & $\mathrm{H}_{2} \mathrm{O}$ & 42 \\
\hline 36 & $\mathrm{~V}_{2} \mathrm{O}_{2}\left(\mathrm{O}_{2}\right)_{3}(\mathrm{gln})_{3}{ }^{a a}$ & -694 & $\mathrm{H}_{2} \mathrm{O}$ & 42 \\
\hline
\end{tabular}

${ }^{a} \mathrm{tf}=$ bovine apo-transferrine. ${ }^{b} \mathrm{pp}=$ bovine prostatic acid phosphatase. ${ }^{c} \mathrm{~V}$-BrPO $=$ vanadate dependent bromeperoxidase ${ }^{d} \alpha$-hhip $=\alpha$-hydroxyhippuric acid. ${ }^{e} \mathrm{Hbpa}=$ bis(picolyl)- $\beta$-alanine. ${ }^{f} \mathrm{bpg}=$ bis(picolyl)glycinate. ${ }^{g} \mathrm{H}_{2}$ heida $=N$-(2-hydroxyethyl)iminodiacetic acid. ${ }^{h}$ 3-OH-pic $=3$-hydroxypicolinic acid. ${ }^{i}$ the intensity ratio depends on $\mathrm{pH}$; the first value indicates the dominant signal. ${ }^{j} 22 \%$ and $35 \%$, respectively, with $43 \%\left[\mathrm{VO}\left(t \mathrm{BuO} \mathrm{O}_{2}\right)\left(\mathrm{H}_{2} \mathrm{O}\right)_{x}\right]^{2+}$, at -531 ppm. ${ }^{k} 3$-OH-pa $=3$-hydroxy-picolylamide. ${ }^{l} 3: 2 .{ }^{m} 44: 56 .{ }^{n} \mathrm{pa}=$ picolinamide. ${ }^{o} \mathrm{Hpca}=2$-pyrazinecarboxylic acid. ${ }^{p}$ bpy $=2,2^{\prime}-$-bipyridine ${ }^{q}$ phen $=$ 1,10-phenanthroline. ${ }^{r}$ pcaa $=2$-pyrazinecarboxyamide. ${ }^{s} \mathrm{Hpic}=$ picolinic acid. ${ }^{t} \mathrm{H}_{2} \mathrm{ox}=$ oxalic acid. ${ }^{\mu}$ 3-phlact $\mathrm{H}_{2}=3$-phenyllactic acid. ${ }^{v} \mathrm{H}_{2}$ Salhyb $=$ Schiff base from salicylaldehyde and 4-hydroxybutanoic acid hydrazide. ${ }^{w} \mathrm{pzH}=$ pyrazole, $\mathrm{HB}(\mathrm{pz})_{3}=\operatorname{tris}\left(1 H\right.$-pyrazol-1-yl)boron hydride. ${ }^{x}$ ma $=$ maltol. ${ }^{y}$ ur $=$ uridine. ${ }^{z}$ asn $=$ asparagine. ${ }^{a}{ }^{a} \ln =$ glutamine.

by Sergienko. ${ }^{21}$ Considering the peroxo ligand as a bidentate one, the most widespread structure is the pentagonal bipyramid found with monoperoxo, as well as for diperoxo derivatives. Very few cases of a sixfold pentagonal pyramid have been reported, ${ }^{28}$ mainly for diperoxo complexes, for recent examples see 26, 29, 32, 33, 37 and 40.

The structural features of the peroxovanadium species summarized in Table 1 are in agreement with those of previously synthesized complexes. ${ }^{1,3,8,20,21}$ If the typical distortions observed in the coordination polyhedra for different vanadium species are considered, ${ }^{21}$ the features can be summarised as in Fig. 1: geometric parameters are very similar, IR frequencies are comparable as well and the oxo and peroxo groups are in cis position.
This is true also with more complicated, often polynuclear, structures: see, as just a few examples, complexes 10,39 and related structures. ${ }^{32-34,48,55}$

A review with a collection of salient UV-vis data for monoperoxo vanadium species recently appeared. ${ }^{27}$

Quite different is the scenario of the ${ }^{51} \mathrm{~V}-\mathrm{NMR}$ chemical shifts, related data are collected in Table 2 . It is evident that the range where monoperoxo species resonate (from -630 to $-510 \mathrm{ppm}$ from $\mathrm{VOCl}_{3}$ ) is quite far away from that of diperoxo vanadates (from -740 to $-690 \mathrm{ppm}$ ). Such a difference has been often used to study the formation equilibria of the various peroxo derivatives, as a function of the excesses of $\mathrm{H}_{2} \mathrm{O}_{2}$. It is to be recalled here that, when vanadates are dissolved in aqueous solutions, in the presence 
Table 3 Selected physicochemical properties of molybdenum peroxo complexes

\begin{tabular}{|c|c|c|c|c|c|c|c|c|c|}
\hline \multirow[b]{2}{*}{$\mathrm{N}$} & \multirow[b]{2}{*}{ Complex } & \multicolumn{3}{|c|}{ Bond lengths/ $\AA$} & \multicolumn{4}{|l|}{$\mathrm{IR} / \mathrm{cm}-1$} & \multirow[b]{2}{*}{ Ref. } \\
\hline & & $\mathrm{Mo}=\mathrm{O}$ & $\mathrm{Mo}\left(\mathrm{O}_{2}\right)$ & $\mathrm{O}-\mathrm{O}$ & $\mathrm{Mo}=\mathrm{O}$ & $\left(\mathrm{MoO}_{2}\right)_{\mathrm{s}}$ & $\left(\mathrm{MoO}_{2}\right)_{\text {as }}$ & $\mathrm{O}-\mathrm{O}$ & \\
\hline & Monoperoxo & & & & & & & & \\
\hline 59 & $\mathrm{MoO}\left(\mathrm{O}_{2}\right)(\mathrm{ketim})_{2}{ }^{a}$ & 1.673 & $1.936,1.951$ & - & - & & & & 66 \\
\hline 60 & $\mathrm{MoO}\left(\mathrm{O}_{2}\right) \mathrm{Cl}_{2}\left(\mathrm{OPMePh}_{2}\right)_{2}$ & 1.705 & $1.839,1.904$ & 1.316 & 956 & 597 & 550 & 920 & 67,68 \\
\hline 61 & $\mathrm{MoO}\left(\mathrm{O}_{2}\right) \mathrm{Cl}_{2}(\mathrm{dppmO})^{b}$ & & & & 965 & & & 920 & 68 \\
\hline 62 & $\left(\mathrm{NH}_{4}\right)_{2}\left[\mathrm{Mo}_{2} \mathrm{O}_{2}\left(\mathrm{O}_{2}\right)_{2}(\mu-\mathrm{OH})_{2}(\mathrm{ox})_{2}\right]^{c}$ & 1.688 & $1.962,1.976$ & 1.458 & 920 & ca. 650 & ca. 600 & 874 & 69 \\
\hline 63 & $\mathrm{MoO}\left(\mathrm{O}_{2}\right)(\mathrm{QO})_{2}{ }^{d}$ & & & & 960 & & & 915 & 70 \\
\hline 64 & $\begin{array}{l}\mathrm{Mo}_{4} \mathrm{O}_{6}\left(\mathrm{O}_{2}\right)_{2}\left(\mu_{3}-\mathrm{O}\right)_{2}\left\{\left(\mu_{2}-\mathrm{O}\right.\right. \\
\left.\mu_{3}-\mathrm{OC}_{8} \mathrm{H}_{14}\right\}_{2}(\mathrm{OPMePh})_{2}{ }^{e}\end{array}$ & 1.659 & $1.894,1.910$ & 1.395 & 953 & 664 & 649 & 889 & 71 \\
\hline 65 & $\mathrm{MoO}\left(\mathrm{O}_{2}\right) \mathrm{Cl}_{2}(\mathrm{dmso})_{2}{ }^{f}$ & 1.675 & $1.856,1.913$ & 1.324 & $p$ & $p$ & $p$ & 1138 & 72 \\
\hline 66 & $\begin{array}{l}\mathrm{CpMoO}\left(\mathrm{O}_{2}\right) \mathrm{CH}_{3}{ }^{g} \\
\text { Diperoxo }\end{array}$ & & & & 951 & & 565 & 877 & 73 \\
\hline $67 a$ & {$\left[\mathrm{Ph}_{3} \mathrm{P}\left(\mathrm{CH}_{2}\right)_{3} \mathrm{PPh}_{3}\right]\left[\mathrm{MoO}\left(\mathrm{O}_{2}\right)_{2} \mathrm{Ox}\right] \cdot \mathrm{H}_{2} \mathrm{O}^{c}$} & & & & 937 & 690 & 580 & 855 & 74 \\
\hline $67 \mathrm{~b}$ & $\left(\mathrm{NH}_{4}\right)_{2}\left[\mathrm{MoO}\left(\mathrm{O}_{2}\right)_{2}(\mathrm{ox})\right]^{c}$ & 1.671 & $1.919,1.955$ & 1.475 & 967 & ca. 650 & ca. 600 & 865 & 69 \\
\hline $68 \mathrm{a}$ & $\left(\mathrm{NH}_{4}\right)_{2}\left[\mathrm{MoO}\left(\mathrm{O}_{2}\right)_{2}\left(\mathrm{H}_{2} \text { cit }\right)\right]^{h}$ & & & & 954 & $c a .650$ & $c a .600$ & 856 & 69 \\
\hline $68 \mathrm{~b}$ & $\mathrm{~K}_{4}\left[\mathrm{MoO}\left(\mathrm{O}_{2}\right)_{2} \mathrm{cit}\right] \cdot 4 \mathrm{H}_{2} \mathrm{O}^{h}$ & 1.688 & $1.933,1.985$ & & 946 & 650 & 577 & 853 & 75 \\
\hline $68 c$ & $\begin{array}{l}\mathrm{K}_{4}\left[\mathrm{MoO}\left(\mathrm{O}_{2}\right)_{2}(\mathrm{Hcit}) \mathrm{H}(\mathrm{Hcit})\left(\mathrm{O}_{2}\right)_{2} \mathrm{OMo}\right] \\
6 \mathrm{H}_{2} \mathrm{O}^{h}\end{array}$ & 1.684 & $1.926,1.975$ & & 942 & 647 & 582 & 857 & 75 \\
\hline 69 & $\left(\mathrm{NH}_{4}\right)_{2}\left[\mathrm{MoO}\left(\mathrm{O}_{2}\right)_{2}\left(\mathrm{H}_{2} \operatorname{tart}\right)\right] \cdot 2 \mathrm{H}_{2} \mathrm{O}^{i}$ & & 1.0 .000 & & 950 & ca. 650 & ca. 600 & 848 & 69 \\
\hline 70 & $\left(\mathrm{NH}_{4}\right)_{2}\left[\mathrm{MoO}\left(\mathrm{O}_{2}\right)_{2}\left(\mathrm{H}_{2} \mathrm{glyc}\right)\right] \cdot 0.5 \mathrm{EtOH}^{j}$ & 1.680 & $\begin{array}{l}1.941,1.986 \\
1.952,1.973\end{array}$ & 1.484 & 956,930 & ca. 650 & $c a .600$ & 849 & 69 \\
\hline 71a & $\left(\mathrm{NH}_{4}\right)_{2}\left[\mathrm{MoO}\left(\mathrm{O}_{2}\right)_{2}(\mathrm{Hmal})\right] \cdot \mathrm{H}_{2} \mathrm{O}^{k}$ & & & & 948 & ca. 650 & ca. 600 & 856 & 69 \\
\hline $71 b$ & $\mathrm{~K}_{2 \mathrm{n}}\left[\mathrm{MoO}\left(\mathrm{O}_{2}\right)_{2}(S-\mathrm{Hmal})\right]_{\mathrm{n}} \cdot \mathrm{nH}_{2} \mathrm{O}^{k}$ & 1.693 & $\begin{array}{l}1.942,1.972 \\
1.942,1.967\end{array}$ & & 947 & 639 & 576 & 859 & 75 \\
\hline 72 & $\mathrm{MoO}\left(\mathrm{O}_{2}\right)_{2}\left(\mathrm{OPMePh}_{2}\right)_{2}$ & $\begin{array}{l}1.665 \\
1.918,1.959\end{array}$ & $\begin{array}{l}1.919,1.951 \\
1.471\end{array}$ & 1.473 & 951 & 657 & 582 & 865 & 76 \\
\hline 73 & $\mathrm{Mo}(\mathrm{O})\left(\mathrm{O}_{2}\right)_{2}\left(\mathrm{dppmO}_{2}\right)^{b}$ & 1.63 & $\begin{array}{l}1.813,1.894 \\
1.802,1.962\end{array}$ & $\begin{array}{l}1.404 \\
1.420\end{array}$ & 961,953 & & & 864,875 & 68 \\
\hline 74 & $\mathrm{MoO}\left(\mathrm{O}_{2}\right)_{2}\left(\mathrm{H}_{2} \mathrm{O}\right)\left(\mathrm{OPMePh}_{2}\right)$ & 1.671 & $\begin{array}{l}1.909,1.934 \\
1.909,1.938\end{array}$ & $\begin{array}{l}1.450 \\
1.461\end{array}$ & 951 & 716 & 693 & 891 & 71 \\
\hline 75 & $\mathrm{PPh}_{4}\left[\mathrm{MoO}\left(\mathrm{O}_{2}\right)_{2}(\mathrm{QO})\right]^{d}$ & 1.684 & $\begin{array}{l}1.910,1.948 \\
1.909,1.953\end{array}$ & & 945 & 720 & 645 & 810,845 & 70 \\
\hline 76 & {$\left[\mathrm{MoO}\left(\mathrm{O}_{2}\right)_{2} 4,4^{\prime} \text {-bipy }\right]_{\mathrm{n}}{ }^{l}$} & & & & 927 & 620 & 558 & 843 & 77 \\
\hline 77 & $\begin{array}{l}{\left[\mathrm{PPh}_{4}\right]_{2}\left[(\mathrm{Me})_{2} \mathrm{SiO}_{2}\left\{\mathrm{Mo}_{2} \mathrm{O}_{2}(\mu-\right.\right.} \\
\left.\left.\left.\mathrm{O}_{2}\right)_{2}\left(\mathrm{O}_{2}\right)_{2}\right\}\right]\end{array}$ & 1.681 & $\begin{array}{l}1.924,1.934 \\
1.903,1.986\end{array}$ & $\begin{array}{l}1.466,1.474 \\
1.483,1.479\end{array}$ & 971,958 & 585 & 528 & 868 & 78 \\
\hline 78 & $\begin{array}{l}{\left[\mathrm{PPh}_{4}\right]_{2}\left[(i-\mathrm{Bu})_{2} \mathrm{SiO}_{2}\left\{\mathrm{Mo}_{2} \mathrm{O}_{2}(\mu-\right.\right.} \\
\left.\left.\left.\mathrm{O}_{2}\right)_{2}\left(\mathrm{O}_{2}\right)_{2}\right\}\right]\end{array}$ & 1.680 & $\begin{array}{l}1.925,1.930 \\
1.917,1.995\end{array}$ & $\begin{array}{l}1.479,1.467, \\
1.475,1.470\end{array}$ & 963,948 & 584 & 526 & 866 & 78 \\
\hline 79 & $\begin{array}{l}{\left[\mathrm{PPh}_{4}\right]_{2}\left[(\mathrm{Me})\left(\mathrm{CH}_{2} \mathrm{Cl}\right) \mathrm{SiO}_{2}\left\{\mathrm{Mo}_{2} \mathrm{O}_{2}(\mu-\right.\right.} \\
\left.\left.\left.\mathrm{O}_{2}\right)_{2}\left(\mathrm{O}_{2}\right)_{2}\right\}\right]\end{array}$ & 1.682 & $\begin{array}{l}1.926,1.926 \\
1.909,1.996\end{array}$ & $\begin{array}{l}1.469,1.464, \\
1.479,1.474\end{array}$ & 966 & 585 & 525 & 866 & 78 \\
\hline 80 & $\mathrm{~K}_{8}\left[\mathrm{Mo}_{4} \mathrm{O}_{12}\left(\mathrm{O}_{2}\right)_{2}\right]$ & $\begin{array}{l}1.716 \\
1.728\end{array}$ & $\begin{array}{l}1.908,1.912 \\
2.200,2.277\end{array}$ & 1.467 & 835,889 & & & 928,951 & 79 \\
\hline 81a & $\mathrm{K}_{2}\left[\mathrm{Mo}_{2} \mathrm{O}_{2}(\mu-\mathrm{O})\left(\mathrm{O}_{2}\right)_{2}\left(\mathrm{H}_{2} \mathrm{O}\right)_{2}\right] \cdot 2 \mathrm{H}_{2} \mathrm{O}$ & $\begin{array}{l}1.688 \\
1.911 \mu\end{array}$ & $\begin{array}{l}1.943,1.957 \\
1.945,1.967\end{array}$ & $\begin{array}{l}1.477,1.483 \\
1.479,1.482\end{array}$ & 961 & 578 & 531 & 855 & 80 \\
\hline $81 b$ & $\begin{array}{l}\left(2-\mathrm{MepyH}_{,} \mathrm{NH}_{4}\right)\left[\mathrm{Mo}_{2} \mathrm{O}_{2}(\mu-\right. \\
\left.\mathrm{O})\left(\mathrm{O}_{2}\right)_{2}\left(\mathrm{H}_{2} \mathrm{O}\right)_{2}\right] \cdot 2 \mathrm{H}_{2} \mathrm{O}^{m}\end{array}$ & $1.677^{\circ}$ & $1.949,1.975$ & $1.483,1.484$ & 973 & 570 & 541 & 851,868 & 80 \\
\hline 81c & $\begin{array}{l}(2-\mathrm{MepyH}, \mathrm{Na})\left[\mathrm{Mo}_{2} \mathrm{O}_{2}(\mu-\right. \\
\left.\mathrm{O})\left(\mathrm{O}_{2}\right)_{2}\left(\mathrm{H}_{2} \mathrm{O}\right)_{2}\right] \cdot 2 \mathrm{H}_{2} \mathrm{O}^{m}\end{array}$ & $\begin{array}{l}1.953 \mu \\
1.680\end{array}$ & $\begin{array}{l}1.938,1.962 \\
1.957,1.986\end{array}$ & $\begin{array}{l}1.482,1.485 \\
1.474,1.485\end{array}$ & 922 & 593 & 559 & 891 & 80 \\
\hline 82 & {$\left[\mathrm{MoO}\left(\mathrm{O}_{2}\right)_{2}(4-\mathrm{MepyO})_{2}\right] \cdot \mathrm{H}_{2} \mathrm{O}^{n}$} & $\begin{array}{l}1.934 \mu \\
1.6885\end{array}$ & $\begin{array}{l}1.933,1.953 \\
1.9314,1.9411\end{array}$ & $\begin{array}{l}1.474,1.481 \\
1.4735 \\
1.4795\end{array}$ & & & & & 81 \\
\hline 83a & {$\left[\mathrm{MoO}\left(\mathrm{O}_{2}\right)_{2}(\mathrm{MBB})\right]^{o}$} & & $1.9314,1.9522$ & & 933 & 602 & 775 & 865 & 82 \\
\hline 83b & {$\left[\mathrm{MoO}\left(\mathrm{O}_{2}\right)_{2}(\mathrm{PBB})\right]^{o}$} & & & & 952 & 598 & 758 & 840 & 82 \\
\hline $83 \mathrm{c}$ & {$\left[\mathrm{MoO}\left(\mathrm{O}_{2}\right)_{2}(\mathrm{MBU})\right]^{\circ}$} & & & & 926 & 606 & 760 & 847 & 82 \\
\hline 83d & {$\left[\mathrm{MoO}\left(\mathrm{O}_{2}\right)_{2}(\mathrm{PBU})\right]^{\circ}$} & & & & 951 & 595 & 760 & 839 & 82 \\
\hline $83 e$ & {$\left[\mathrm{MoO}\left(\mathrm{O}_{2}\right)_{2}(\mathrm{MBTU})\right]^{o}$} & & & & 926 & 607 & 770 & 839 & 82 \\
\hline $83 f$ & $\begin{array}{l}{\left[\mathrm{MoO}\left(\mathrm{O}_{2}\right)_{2}(\mathrm{PBTU})\right]^{\circ}} \\
\text { Tetraperoxo }\end{array}$ & & & & 935 & 618 & 707 & 810 & 82 \\
\hline $84 a$ & $\mathrm{Li}_{2}\left[\mathrm{Mo}\left(\mathrm{O}_{2}\right)_{4}\right] \cdot 4 \mathrm{H}_{2} \mathrm{O}$ & - & $\begin{array}{l}1.989,1.955 \\
1.971,1.951 \\
1.933,1.931 \\
1.977,1.958\end{array}$ & $\begin{array}{l}1.482 \\
1.486 \\
1.477 \\
1.484\end{array}$ & - & 607 & 567 & 842 & 83 \\
\hline
\end{tabular}


Table 3 (Contd.)

\begin{tabular}{|c|c|c|c|c|c|c|c|c|c|}
\hline $\mathrm{N}$. & Complex & \multicolumn{3}{|c|}{ Bond lengths/Å } & \multicolumn{4}{|l|}{$\mathrm{IR} / \mathrm{cm}-1$} & Ref. \\
\hline $84 b$ & $\mathrm{Na}_{2}\left[\mathrm{Mo}\left(\mathrm{O}_{2}\right)_{4}\right] \cdot 4 \mathrm{H}_{2} \mathrm{O}$ & - & $\begin{array}{l}1.970,1.979 \\
1.939,1.960 \\
1.974,1.953 \\
1.931,1.940\end{array}$ & $\begin{array}{l}1.483 \\
1.487 \\
1.481 \\
1.484\end{array}$ & - & 582 & 557 & 836 & 84 \\
\hline
\end{tabular}

${ }^{a}$ ketim $=4$-(2,6-dimethylphenylimino)pent-2-en-1-olate. ${ }^{b} \mathrm{dppmO}_{2}=$ diphenylphosphinomethane oxide. ${ }^{c} \mathrm{H}_{2} \mathrm{ox}=$ oxalic acid, ox $=$ oxalate $\mathrm{C}_{2} \mathrm{O}_{4}{ }^{2-}$. ${ }^{d} \mathrm{QO}=$ 8-quinolinolate. ${ }^{e} \mathrm{C}_{8} \mathrm{H}_{14}=$ cyclooctene. ${ }^{f}$ dmso $=$ dimethylsulfoxide. ${ }^{g} \mathrm{Cp}=\eta^{5}$-cyclopentadienyl. ${ }^{h} \mathrm{H}_{4}$ cit $=$ citric acid. ${ }^{i} \mathrm{H}_{2}$ tart $=$ tartaric acid. ${ }^{j} \mathrm{Hglyc}=$ glycolic acid. ${ }^{k} \mathrm{H}_{2} \mathrm{mal}=$ malic acid. ${ }^{l} 4,4^{\prime}$-bipy $=4,4^{\prime}$-bipyridyl. ${ }^{m}$ 2-Mepy $=2$-methylpyridine. ${ }^{n}$ 4-Mepy $=4$-methylpyridine. ${ }^{o}$ Mannich base, see Scheme 9. ${ }^{p}$ IR data of peroxo complexes likely refer to the parent dioxo precursor reported in the same paper.

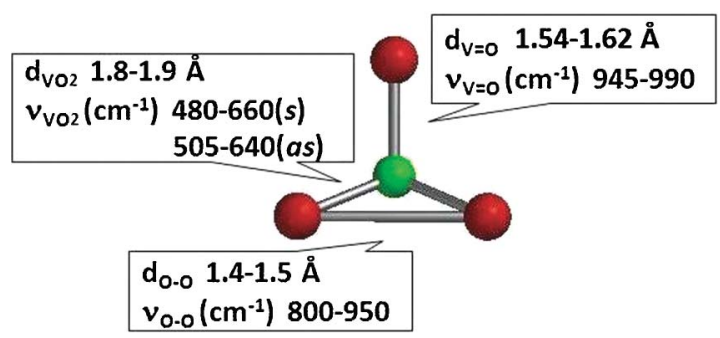

Fig. 1 Physicochemical features of V(v) peroxo complexes.

of hydrogen peroxide, several species can be formed depending on the $\mathrm{pH}$, the ionic strength and the ratio of $\mathrm{H}_{2} \mathrm{O}_{2}: \mathrm{V}$. All of them are in equilibrium and the prevalence of the different types of peroxidic complexes is strongly influenced by $\mathrm{pH}$. Higher values favour species with more peroxo groups bound to the metal.

Several research groups studied such equilibria, particularly to shed light on the nature of the real oxidant in the catalytic systems. ${ }^{1,3}$ More recently, an interesting work appeared, where experimental and computed ${ }^{51} \mathrm{~V}$-NMR chemical shifts were used to assess the solution structures. ${ }^{56}$ In such a way, two high field resonances have been attributed to tetra- $\left(\delta<-730 \mathrm{ppm}\right.$ for $\left.\left[\mathrm{V}\left(\mathrm{O}_{2}\right)_{4}\right]^{3-}\right)$ and tri-peroxovanadates $\left(\delta<-830 \mathrm{ppm}\right.$ for $\left.\left[\mathrm{VO}\left(\mathrm{O}_{2}\right)_{2} \mathrm{OOH}\right]^{2-}\right)$, complexes rarely observed.

A particular example of ${ }^{51} \mathrm{~V}-\mathrm{NMR}$ analysis of monoperoxo species, in water in the presence of proteins as ligands, has been described by Rehder ${ }^{50}$ who showed that mono peroxovanadate bound to bovine apo-transferrine (tf) or to bovine prostatic acid phosphatase (pp) has an almost unbiased chemical shift ( $\delta \cong-600$ ppm) (see Table 2, compounds 43, 44 and 45), while in the presence of vanadium dependent bromo peroxidase (V-BrPO) such a signal is extremely shielded ( $\delta \cong-1155 \mathrm{ppm})$. The high shielding of vanadate in the presence of a peptide ligand has been predicted with DFT calculations. ${ }^{57}$

In the same year, Rehder ${ }^{30}$ published the structure of some oxo monoperoxo vanadium species (complexes 2-6 in Table 1), in such a paper a detailed description of the influence of the nature of the ligands and of the experimental conditions on the ${ }^{51} \mathrm{~V}$-NMR chemical shifts is reported.

To note (see Table 2), that in the presence of ligands such as 3-hydroxypicolinic acid, biligated complexes may undergo a slow equilibrium between two species containing the pyridine nitrogen cis or trans with respect to the peroxo group, as observed in complexes 5 and $\mathbf{4 7}$, thus showing two different ${ }^{51} \mathrm{~V}$-NMR resonances (see Scheme 5). ${ }^{30}$

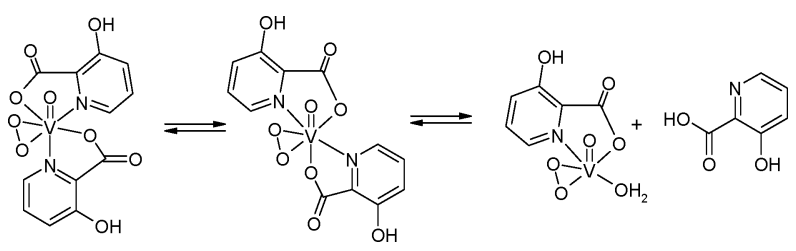

Scheme 5 The exchange equilibria for complex 5.

The use of ${ }^{17} \mathrm{O}-\mathrm{NMR}$, a technique rarely used for peroxo species, considering the difficulties to obtain labelled $\mathrm{H}_{2}{ }^{17} \mathrm{O}_{2}$, is also presented. Notably, the inequivalence of the ${ }^{17} \mathrm{O}-\mathrm{NMR}$ peroxidic signals for the vanadium diperoxo anion was observed. ${ }^{30}$

Complex 1, a dimeric diperoxo species with racemic $\alpha$ hydroxyhippuric acid as the ligand, exhibits in solution a decomposition pattern to its reduced forms, which can be followed with ${ }^{51} \mathrm{~V}-\mathrm{NMR}$, as indicated in Scheme $6 .{ }^{29} \mathrm{~A}$ distinctive behaviour is the formation in solution of a mixed dioxo and oxo-peroxo vanadium(v) dimeric species, which shows two resonances at $\delta=$ -526 and $-580 \mathrm{ppm}$.

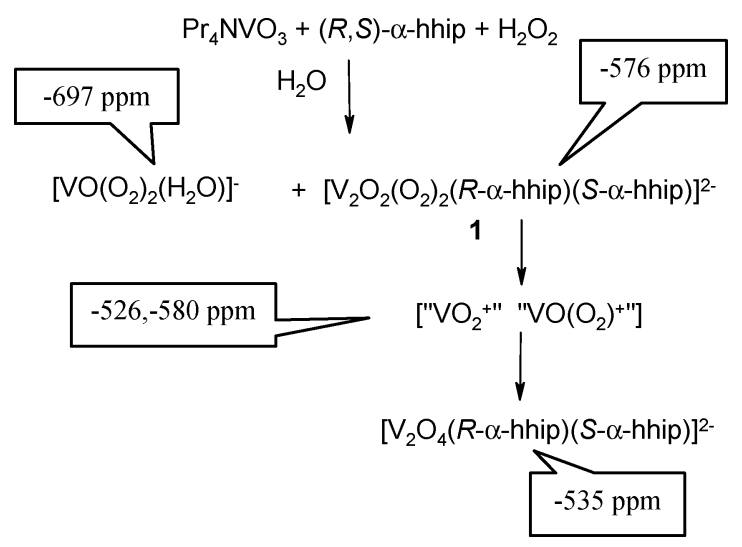

Scheme 6 The decomposition pattern, in aqueous solutions, for complex $\mathbf{1}$ prepared in situ.

Another representative example of the speciation analysis of peroxo vanadates in an acid aqueous solution has been reported 
with complex 34 (see Scheme 7, where only the cationic moiety is indicated). To note, the presence of a basic ligand generates a remarkable difference in the chemical shifts, both on the mono and di-peroxo vanadates, ${ }^{31}$ an effect well known in the literature. ${ }^{58,59}$

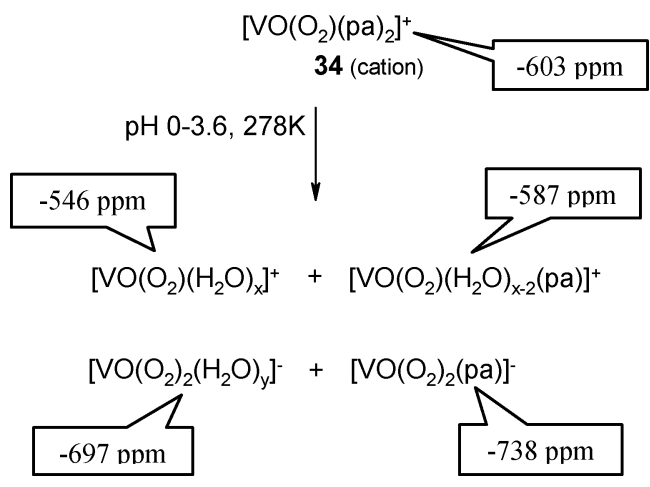

Scheme 7 The equilibria for the cationic moiety of complex 34 in acid water solutions.

In Scheme 8, a similar equilibrium in aqueous solution is shown for the diperoxo vanadium complex $\mathbf{5 1} .^{53}$ The dependence of the vanadium peroxides resonances on the $\mathrm{pH}$ of the solution and the temperature is clearly shown. The peak at $-711 \mathrm{ppm}$ moves toward lower fields with an increase either of the temperature or of the $\mathrm{pH}$ of the solution. The attribution of the peaks has been supported by $2 \mathrm{D}^{1} \mathrm{H}-\mathrm{DOSY}$ experiments, measuring the diffusion rates of the different complexes.

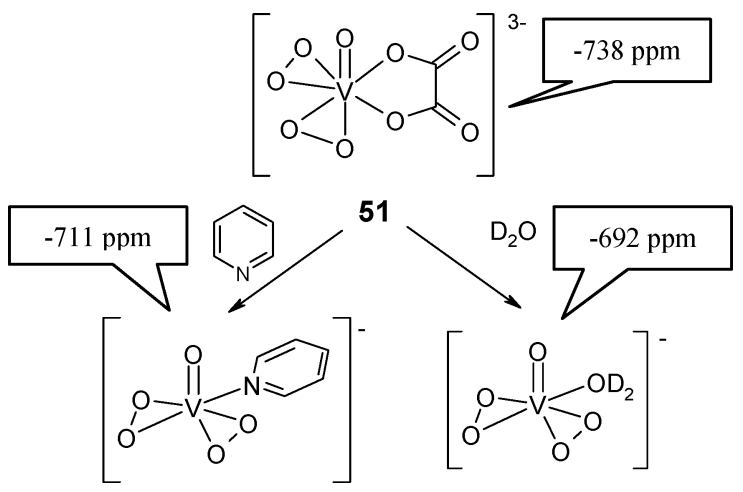

Scheme 8 The exchange equilibria for complex 51, in the presence of pyridine, as measured with ${ }^{51} \mathrm{~V}$-NMR experiments.

A similar work, with oxazole as the ligand, appeared more recently ${ }^{54}$ where the experimental data were also supported with theoretical calculations. A pentagonal pyramidal arrangement for $\left[\mathrm{VO}\left(\mathrm{O}_{2}\right)_{2} \text { (oxazole) }\right]^{-}$is proposed.

Other speciation studies in aqueous solution for peroxo and diperoxo vanadates, in the presence of different types of bio-related ligands, have been reported. ${ }^{51,52}$ Those kinds of investigations were stimulated by the finding of the insulin-enhancing effects exhibited by vanadate and peroxovanadate complexes. ${ }^{60,61}$

Studies with aminoacids or small peptides are, on the other hand, more related to the inhibition of phosphoprotein hydrolysis by the peroxovanadium derivatives ${ }^{46}$ as well as with the modelling of vanadium dependent haloperoxidases. ${ }^{61}$

Also, fluorine containing diperoxovanadate exhibits its ${ }^{51} \mathrm{~V}$ NMR resonance in the typical range $\left(\delta=-711 \mathrm{ppm}\right.$ with a $J_{\mathrm{VF}}$ $\cong 163 \mathrm{~Hz}){ }^{43}$ When the more complex bimetallic species 37 and 38 are dissolved in water, $\left[\mathrm{VO}\left(\mathrm{O}_{2}\right)_{2}\left(\mathrm{H}_{2} \mathrm{O}\right)\right]^{-}$and $\left[\mathrm{VO}\left(\mathrm{O}_{2}\right)_{2} \mathrm{~F}\right]^{2-}$ have been detected as the most important species. ${ }^{47}$

The formation of fluoro diperoxo vanadium anion, from vanadate and hydrogen peroxide, has been observed in a waterhydrophilic ionic liquid $\left(\mathrm{bmimBF}_{4}\right)$ mixture. ${ }^{62}$

Remaining in the field of speciation in aqueous peroxovanadateligands systems, some bio-related works have been published by Salifoglou and colleagues ${ }^{32-34,48,55,63}$ The papers refer to the quite complex equilibria that are taking place in water at physiological conditions, between vanadium and biogenic ligands such as citrate or glycine. Interestingly, polynuclear peroxo complexes are formed with both ligands, species $\mathbf{1 0}$ and $\mathbf{3 9}$ in Table 1.

ESI-MS studies for the amino acid containing vanadium peroxo species have been reported ${ }^{64}$ and compared with previous ones. ${ }^{19,65}$

\section{Peroxo molybdenum complexes}

Also in the case of molybdenum peroxo derivatives, several different types of ligands have been used. Scheme 9 collects the compounds whose solid state structures have been published in recent years. The relevant structural and spectroscopic features are shown in Fig. 2 and in Table 3.

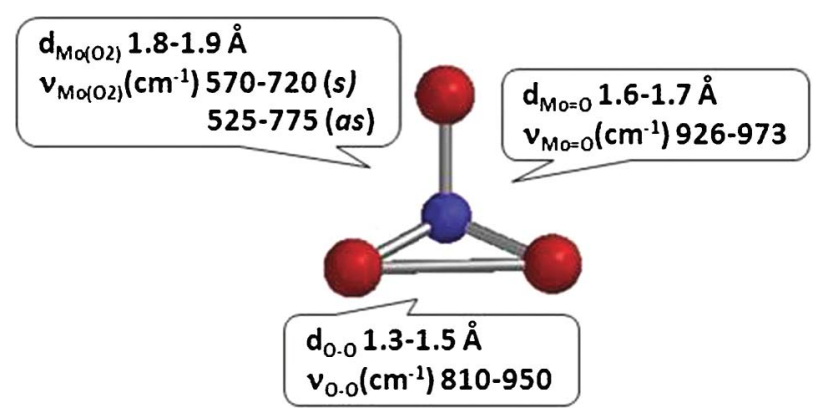

Fig. 2 The physicochemical features of Mo(vi) peroxo complexes.

A typical behaviour of the molybdenum based peroxides is the lower stability of the monoperoxo derivatives as compared with their diperoxo counterparts. This fact is well accounted for by the smaller number of isolated monoperoxo species collected in Scheme 9 and Table 3. Such a feature has been underlined also in the past. ${ }^{1,2,3}$

From the inspection of the solid state structures, it is visible that the derivatives collected here display the same motifs already known: a pentagonal bipyramidal structure, with the oxo oxygen at one apex and the $\eta^{2}$ peroxo moiety(ies) in the equatorial plane cis to the oxo oxygen. The slight length difference between the two Mo-O bonds of the peroxide bridge is a general feature, the longer bond being closer to the site of coordination occupied by the ligand. Therefore, this "hindrance" may well be the reason for such asymmetry.

The IR frequencies related to the $\operatorname{MoO}\left(\mathrm{O}_{2}\right)$ group are, as in the case of the parent vanadium species, in a quite narrow range. To note, the values of $v_{0-0}=810-950 \mathrm{~cm}^{-1}$ are very similar to those measured for the peroxidic oxygens bound to the vanadium atom. On the other hand, Mo metal-oxo and metal-peroxo bonds, respectively, exhibit lower and higher wavenumbers in comparison with vanadium derivatives (see Fig. 1 and 2). 


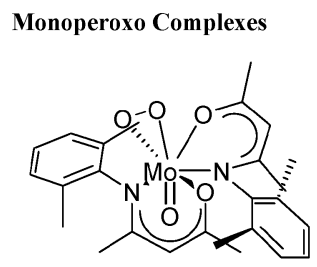

59<smiles>C[PH](OP(C)(Oc1ccccc1)(OP(=O)(O)c1ccccc1)c1ccccc1)(c1ccccc1)c1ccccc1</smiles>

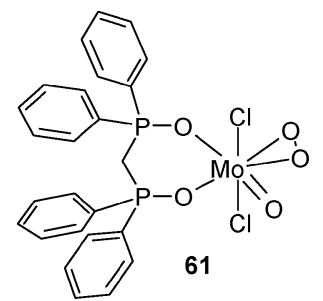

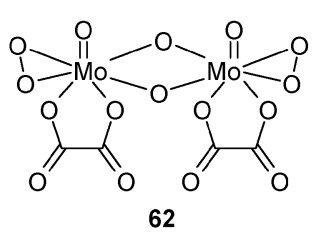

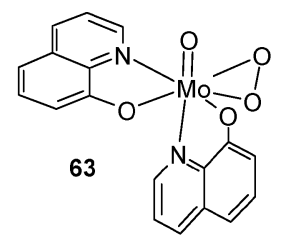<smiles>C[SH](C)O[W](Cl)(Cl)(Cl)(Cl)O[Si](C)(C)O[Si](C)(C)C</smiles><smiles></smiles>

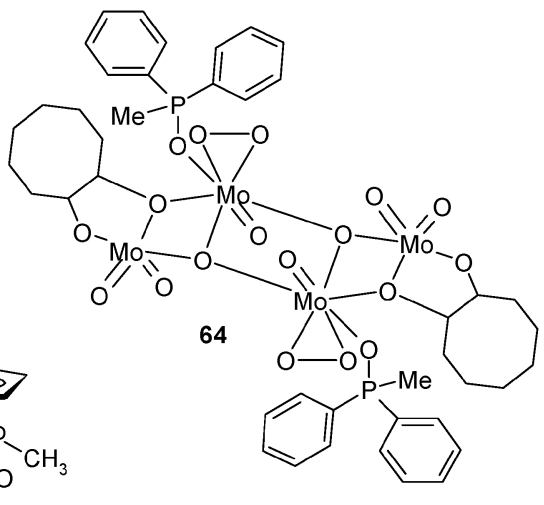

Diperoxo Complexes

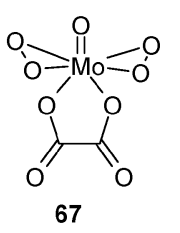

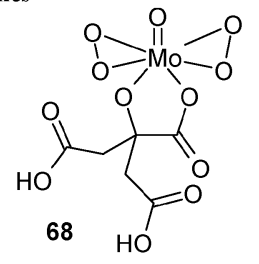

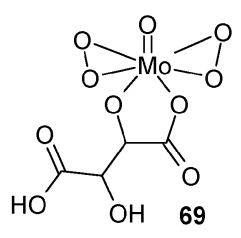<smiles>O=C1COP23(OOO2)OC(=O)ON3O1</smiles><smiles></smiles>

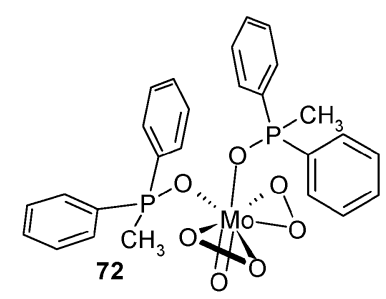

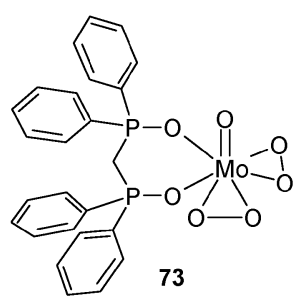<smiles></smiles>

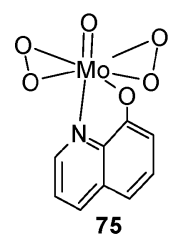

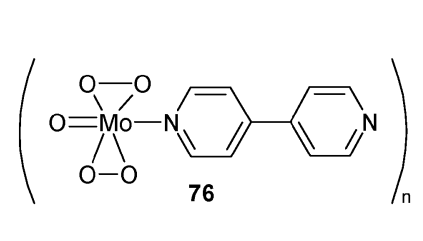

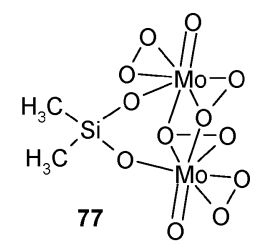

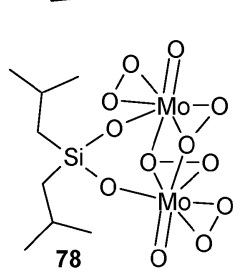

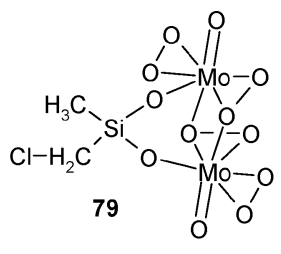

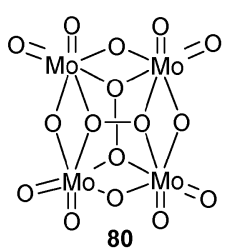

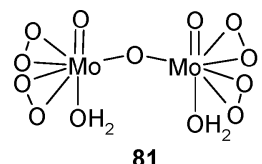
81

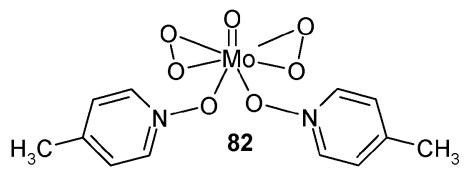<smiles>O=[PH](=O)(O[Na])OCCOO</smiles>

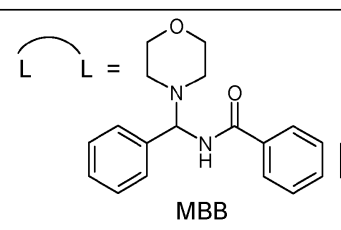<smiles>O=C(NC(c1ccccc1)N1CCCCC1)c1ccccc1</smiles><smiles>CCCCC(NC(N)=O)C(c1ccccc1)N1CCOCC1</smiles><smiles>CCCCCCCC(NC(N)=O)c1ccccc1</smiles><smiles>NC(=S)NC(c1ccccc1)N1CCOCC1</smiles>

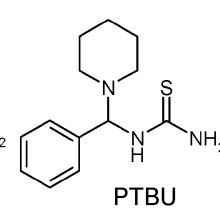

Tetraperoxo Complexes<smiles>[R19][Te]12(OOO1)OO2</smiles>

Scheme 9 The structure of isolated molybdenum(VI) peroxo complexes, numbered as in Table 3 . The charges on the complexes are omitted for clarity.

These features remain nearly unchanged also for polynuclear or polyperoxo species.

Complex 80, a peculiar tetra-molybdenum diperoxo derivative, ${ }^{79}$ exhibits a double $\mu_{4}$ arrangement of the two peroxidic moiety and four $\mu$-oxo bridges with a shorter $\mathrm{Mo}-\mathrm{O}$ bond. The IR frequencies are, however, not very different from those observed in the other species reported in Table 3.

Oxo mono peroxo Mo species 60 and 65 , which contain chloride ligands, ${ }^{67,72}$ display a short $\mathrm{O}-\mathrm{O}$ bond length, $\cong 1.32 \AA$, which is an intermediate value between that of $\mathrm{H}_{2} \mathrm{O}_{2}(1.44 \AA)$ and that of $\mathrm{O}_{2}$ 
(1.21 Å). This could be a characteristic sign for a Mo(v)superoxide species, however the absence of any EPR signal unquestionably points to $\mathrm{Mo}(\mathrm{VI})$-peroxo as the correct electronic configuration.

Still, in the examples of monoperoxo derivatives, complex 66, $\mathrm{CpMoO}\left(\mathrm{O}_{2}\right) \mathrm{CH}_{3}$, is representative of the cyclopentadiene $\mathrm{Mo}(\mathrm{VI})$ species, which are prepared by oxidation of the Mo(II) precursor, ${ }^{73,85}$ through the formation of a dioxo $\mathrm{Mo}(\mathrm{VI})$ intermediate, with $t$-butylhydroperoxide (TBHP).

As already discussed in the previous paragraph for vanadium compounds, it cannot be anticipated that the structure in solution is identical or even similar to the solid state one. To obtain information concerning the solution structure, the one actually involved in reactivity, the use of heteronuclear NMR is a key tool. However, in the case of peroxomolybdate, albeit application of ${ }^{95} \mathrm{Mo}$ or ${ }^{97} \mathrm{Mo}$ NMR spectroscopy is possible, ${ }^{86}$ not many studies have been published. In some instances the analysis of the equilibria can be done by following the signals of the ligands. In particular, when phosphorous is present, ${ }^{31} \mathrm{P}$-NMR technique can be applied conveniently.

\section{Theoretical calculations}

Theoretical calculations have been performed for several $\mathrm{V}$ and Mo peroxo species, in particular to obtain an indication on the stability of the different catalysts that can be formed upon coordination of peroxide to the metal centre, or to shed light on the mechanistic pathway of oxidation.

Worthy to note are reports that refer to the application of different types of theoretical analysis to highlight the reasons behind the chemoselectivity shown by peroxo molybdenum species.

When divanadium triperoxo complexes $\mathbf{3 5}$ and $\mathbf{3 6}^{42}$ were analysed with DFT methods, ${ }^{87}$ it was shown that the peroxo groups (bridged vs. side-on) are non equivalent. Furthermore, the electrophilicity of the bridged peroxo group is higher, thus rendering them as the preferential site of attack for bromide ions in oxidative bromination processes.

DFT calculations were also performed to discriminate between the different mechanistic proposals for olefin epoxidation, with $\mathrm{H}_{2} \mathrm{O}_{2}$ catalysed by salen or salan (ligands prepared from salicylaldehyde derivatives and diamines) vanadium complexes. ${ }^{88-90}$ As in several previous instances, also with quite complex systems, evidence favouring the Sharpless mechanism has been obtained.

The same theoretical approach has been used to analyse the structure of the intermediates involved in the oxidations of hydrocarbons with $\mathrm{H}_{2} \mathrm{O}_{2}, \mathrm{~V}(\mathrm{v})$ and carboxylic acids. The proposed formation of ozone in such processes appears to be substantiated by the calculations. ${ }^{91,92}$

The same authors have also used DFT calculations to model the interaction of water molecules with mono and di-peroxo vanadates. ${ }^{93}$

A similar approach has been used to identify a mechanistic pathway for the oxidation of nitrogen with peroxo vanadates. The fate of the $\mathrm{N}_{2} \mathrm{O}$ formed appears to be dominated by its addition to the $\mathrm{V}=\mathrm{O}$ bond to form hyponitrite. ${ }^{94}$

A few years before, Bühl used density functional studies to prove once again the principal steps in the oxidation of olefins with peroxo vanadium derivatives. In the same paper, he also used such studies, taking into account the effects of solvation and dynamics, to model the ${ }^{51} \mathrm{~V}$-NMR chemical shifts in aqueous solutions. A good agreement with experimental data was obtained for the diperoxo complexes containing imidazole and pyridine ligands. ${ }^{95}$

In a paper authored by Shiga,${ }^{96}$ the paired interacting orbitals analysis (PIOs) showed that the olefin epoxidation reaction, modelled with ethylene, is influenced by the variation of overlap repulsion between the orbitals of the substrate and the occupied orbitals of the Mo peroxo complex. When increasingly hindered amines are coordinated to the metal centre, such repulsion rises, thus rendering the reaction less feasible. On the other hand, the energy of the MO orbitals of the alkoxy species, which forms before the hydrogen abstraction step, appears not to be influenced by the coordination of the amines.

DFT calculations at the B3LYP level were used to explain the chemoselectivity observed in the electrophilic oxidation of unsaturated sulfides to the corresponding sulfoxides (or even sulfones). ${ }^{97}$ Such selectivity has been explained on the basis of the predominant orbital interactions observed in the calculated TS. It has been shown that the energy level of the sulfur lone pair (HOMO) is sufficiently high with respect to that of the $\pi$ electrons (HOMO-1) of the double bond to account for the experimental data. Further calculation, refined with the addition of solvent effects (SCRF approach), allowed the prediction of a decrease of the chemoselectivity with increasing solvent polarity.

Very recently, the mechanism of catalysis for an $\eta^{5}$ cyclopentadienyl molybdenum species, used in the epoxidation of olefins with TBHP (complex $\mathbf{6 6}^{73}$ see Scheme 10), was studied with DFT calculations at the B3LYP level. ${ }^{98}$

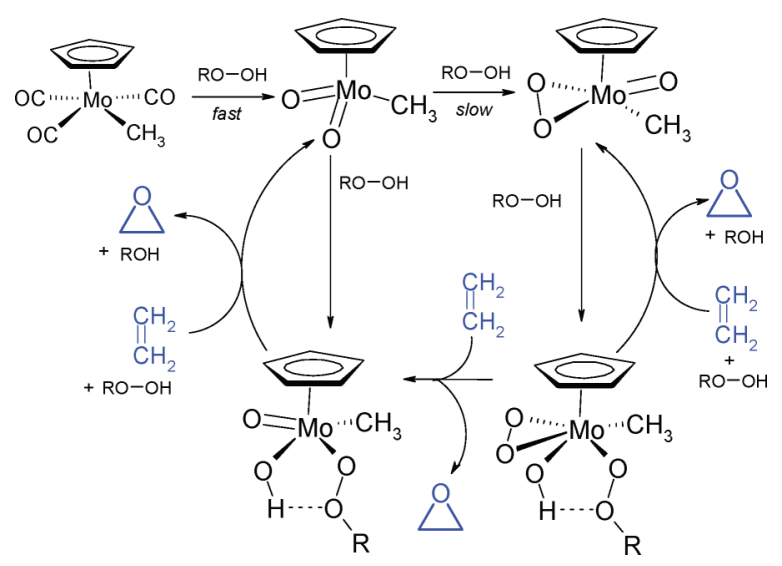

Scheme 10 The calculated reaction mechanism for olefin epoxidation with alkylhydroperoxides, catalysed by complex $\mathbf{6 6}$.

In this example the barriers obtained for several different pathways are very similar, therefore clear-cut evidence of which one is operating was not available. The theoretical data (Scheme 10) are in agreement with the mechanistic studies reported from the same research group. ${ }^{73}$ The authors also indicate that the calculated solvent effect is negligible.

\section{Reactivity}

The enhancement of the reactivity of peroxides in the presence of metal catalysis is very well known, moreover, for several types of reactions the mechanistic details have been elucidated. To note, in 
a number of cases, support for the mechanistic proposals has been obtained with theoretical calculations.

With very few notable exceptions, ${ }^{1,3,8,17} \mathrm{Mo}(\mathrm{VI})$ and $\mathrm{V}(\mathrm{v})$ peroxo species behave as electrophilic oxygen transfer reagents, thus reacting preferentially with the more nucleophilic functional group present in the molecule. In several instances the chemoselectivity observed is very high, when not exclusive. The simple and general equation that describes these reactions is shown in Scheme 11.

$$
\begin{aligned}
& \mathrm{XO}-\mathrm{OH}+\mathrm{Sub} \frac{\mathrm{V}^{\mathrm{V}} \text { catalyst }}{\mathrm{Mov} \text { catalyst }} \text { SubO }+\mathrm{X}-\mathrm{OH} \\
& \mathrm{X}=\mathrm{H} \text {, alkyl } \\
& \mathrm{Sub}=\text { phosphines, amines, sulfides, sulfoxides, alkenes, alcohols, etc. }
\end{aligned}
$$

Scheme 11 The oxidation reactions with peroxides catalysed by V(v) or $\mathrm{Mo}(\mathrm{VI})$ precursors.

From the mechanistic point of view, when a nucleophile reacts with an $\eta^{2}$-peroxometal complex, a direct attack on the substrate by the electrophilic oxygen is envisaged and no intermediates are present, but only a spirocyclic transition state is involved along the reaction coordinate (Sharpless mechanism) $)^{1,3,8}$

This mechanism has a close relationship with the one accepted for the oxidation reactions with peracids. A different mechanism was proposed in the past, ${ }^{1,2,3,8}$ with the occurrence of a peroxometallacyclic intermediate. However, experimental and theoretical evidence points against such a route (see also the previous paragraph), with a few exceptions observed with specific substrates. Here, we will not recall in detail those quite old and meticulous studies, which have already been collected and described recently. ${ }^{1,2}$

As far as vanadium peroxides are concerned, there is also evidence of a quite complex radical oxidative reactivity toward alkanes and aromatics, which has been thoroughly examined by diverse research groups, also very recently. ${ }^{99,100}$

It may be, however, interesting to note that sometimes "old oxidation chemistry" is rediscovered, without taking entirely into consideration the recent achievements in the field. An example is the oxidation of chalcogenides with the known Mimoun complex ${ }^{8,23} \mathrm{MoO}\left(\mathrm{O}_{2}\right)_{2} \mathrm{HMPA}\left(\mathrm{H}_{2} \mathrm{O}\right){ }^{101}$

A peculiar aspect in the $\mathrm{Mo}(\mathrm{VI})$ catalysis appears when metal precursors are treated with a very high excess of hydrogen peroxide, particularly in basic media. In such conditions, a composite mixture of peroxo complexes forms, where mono, di and tetraperoxo derivatives are present in low amounts, while the triperoxo species is the predominant one. This latter compound is able, in the absence of other reactive substrates, to oxidize $\mathrm{H}_{2} \mathrm{O}_{2}$ to singlet oxygen. ${ }^{102}$

To note, an ample collection (up to the end of 2003) of the works appearing in the literature concerning the reactivity of vanadium and molybdenum peroxo derivatives toward several functional groups is present in the Patai book dedicated to the chemistry of peroxides. ${ }^{1}$

A hot research topic connected with the reactivity of vanadium peroxo derivatives refers to model systems for the oxidative ability of vanadium-dependent haloperoxidases enzymes, VHPOs. Such natural systems efficiently perform the oxidation of halides to hypohalous acids and of sulfides to the corresponding sulfoxides.
In particular, the accepted mechanism for such reactions can be sketched as indicated in Scheme 12.

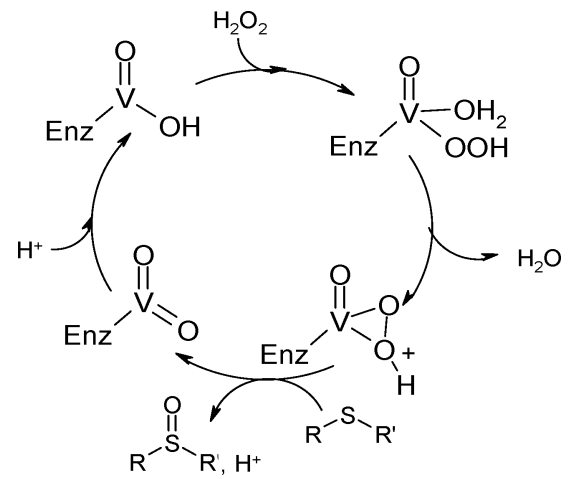

Scheme 12 The simplified mechanism for VHPOs catalysed sulfoxidations

Complex 4, $\mathrm{K}\left[\mathrm{VO}\left(\mathrm{O}_{2}\right)\right.$ heida $],{ }^{30,103}$ is likely the best established functional model for VHPOs, such a complex has been used to propose a mechanistic pathway, where a key step is the protonation of a peroxo oxygen to form an hydroperoxo intermediate, ${ }^{30}$ which reacts more easily with the nucleophilic substrate, i.e. halides or sulfides.

In order to locate the site of the protonation, investigations were performed with experimental spectroscopy ${ }^{104}$ (XANES, Xray absorption near-edge) and DFT calculations on such a model compound. ${ }^{105}$ Both experiments point at the $\eta^{2}$-peroxo ligand as the protonation site, thus supporting the hypothesis that a key role is also being played by a hydroperoxo intermediate in the catalytic cycle of the VHPOs functional model. DFT was in fact used by the same research group to investigate the structural, electronic, and catalytic properties of the vanadium cofactor in VHPOs, ${ }^{106,107}$ also as a function of environment and protonation state. ${ }^{108}$ These studies demonstrated the important role of protonation in the cofactor activation.

Quite surprisingly, at odds with the common knowledge, there have been a couple of works where a reactivity comparison of two oxo peroxo vanadium complexes with their dioxo reduced counterparts was performed, and the results obtained indicate that the dioxo species is the more active.

In the first case, the reactions analysed are the oxidation with $\left[\mathrm{VO}\left(\mathrm{O}_{2}\right) \mathrm{tpa}_{\mathrm{PF}}\right.$ and $\left[\mathrm{VO}_{2} \mathrm{tpa}_{6}\right] \mathrm{PF}_{6}$ (tpa $=$ tris- $(3-$ pyridyl)methylamine) of $\alpha$-terpinene to $p$-cymene and of 2,6-ditert-butyl phenol to quinone. ${ }^{109}$

The other more recent example ${ }^{110}$ refers to the oxygen transfer behaviour of $\left[\mathrm{VO}\left(\mathrm{O}_{2}\right)\left(t \mathrm{Bu}_{2}\right.\right.$ bpy $\left.)\right] \mathrm{BF}_{4}$ and $\left[\mathrm{VO}_{2}\left(t \mathrm{Bu}_{2}\right.\right.$ bpy $\left.)\right] \mathrm{BF}_{4}$ $\left(t \mathrm{Bu}_{2}\right.$ bpy $=4,4^{\prime}$-di-tert-butylbipyridine $)$ toward hydroquinone, TEMPOH and phosphines.

A critical collection of papers related to the catalytic oxidations with vanadium complexes was published in $2003 .{ }^{111}$

\section{Bromination}

In connection with the studies aimed at mimicking the reactivity of VHPOs enzymes, complex $\mathbf{2 4}$ has been studied in the oxidative bromination of 1,3,5-trimethoxybenzene (TMB). A 90\% yield of BrTMB was obtained in acid conditions, in a short reaction time. 
A fast reaction is observed also with triphenylphosphane, while the analogous reaction with methylphenyl thioether is much slower. ${ }^{40}$

Complexes $\mathbf{3 5}$ and 36, characterized by the dimeric triperoxo structure, are fast and efficient oxidants of bromide, thus being mediators of the bromination reaction of organic substrates in an aqueous organic media. ${ }^{42}$ Such a dimeric structure resembles the intermediate proposed by Butler ${ }^{112}$ in the catalytic cycle of VHPOs mimicking systems. The analogous mononuclear complexes $\mathbf{2 7}$ and $\mathbf{2 8}$, are inactive.

Not considering only isolated peroxo complexes, there are vanadium oxo species which, in the presence of $\mathrm{H}_{2} \mathrm{O}_{2}$, can efficiently act as a functional mimic of VHPOs enzymes. A nice example refers to the $\mathrm{V}(\mathrm{v})$ amine triphenolate derivatives (Fig. 3), which brominate 1,3,5-trimethoxybenzene to 2,4,6-trimethoxybromobenzene with yields and TONs up to $92 \%$ and 1260 , respectively, in acid conditions. ${ }^{113}$

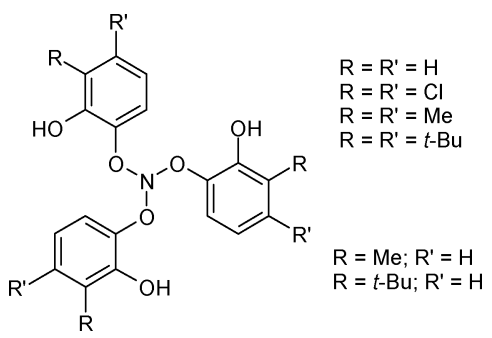

Fig. 3 Triphenolate amine ligands.

Effective mimicking of VHPOs was also obtained by using a tripodal ligand, bis[(1-methylimidazol-2yl)methyl] 2-(pyridyl-2yl)ethyl amine, bound to a $V(v)$ oxo centre in the presence of hydrogen peroxide. ${ }^{114}$ This complex shows a structural similarity with the reduced form of the prosthetic group of VHPOs and resembles their catalytic activity in bromide to bromine oxidation.

The anchoring of peroxovanadates to soluble polymers appears to be a promising field. A recent example ${ }^{49}$ shows the activity of supported peroxo species $\mathbf{4 0}$ and $\mathbf{4 1}$ in bromination of aromatics.

\section{Oxidation of sulfur and nitrogen containing substrates}

From the synthetic point of view, the oxidation of prochiral thioethers retains a great significance as a testing reaction for the catalytic activity of chiral non racemic complexes. In such a field, several nice examples of catalysts have been reported, and, specifically with vanadium species, Bolm collected topical reports in $2003 .{ }^{115}$ To note, often the synthetically useful procedures do not rely on the use of hydrogen peroxide, as there are alkylhydroperoxides that are much more reactive and selective with the catalysts studied. ${ }^{116}$ Clearly, from the sustainable point of view, this should be changed in the near future. An improvement in this area has recently been obtained by Licini and colleagues ${ }^{113}$ They reported the use, in turn-over conditions, of vanadium amine triphenolate derivatives as the catalysts in sulfoxidation reactions with $\mathrm{H}_{2} \mathrm{O}_{2}$. Only an almost quantitative yield of sulfoxide was detected, even in the presence of an equimolar amount of oxidant. Furthermore, the catalyst loading was decreased down to $0.01 \%$, observing TONs and TOFs up to 9900 and $8000 \mathrm{~h}^{-1}$, respectively. ${ }^{113}$

An oxovanadium complex, containing tridentate Schiff bases derived from $\beta$-amino alcohols (see Fig. 4), has been tested in the enantioselective oxidation of methyl phenyl sulfide with hydrogen

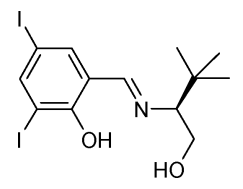

Fig. 4 The Schiff base ligand, efficient in asymmetric catalysis.

peroxide. At low temperature, with an appropriate substitution pattern in the ligand, up to $98 \%$ e.e. was obtained. The scope of the reaction was not checked with other substrates. ${ }^{117}$

More recently, the oxidation of sulfur containing substrates is receiving increasing interest, in connection with the search for a sustainable oxidative desulfurization procedure for fuels. In particular, the complete oxidation of difficult to oxidize substrates, such as aromatic sulfides, is still a challenging task, with benzothiophene, dibenzothiophene and their derivatives being the target substrates.

In this respect, the catalytic activity of $\mathrm{V}$ and $\mathrm{Nb}$ oxoperoxocomplexes, containing a Schiff-base ligand, was analysed in the $\mathrm{H}_{2} \mathrm{O}_{2}$ oxidation of methyl phenyl sulfide and benzothiophene. $\mathrm{V}(\mathrm{v})$ complexes are less reactive but more selective than the corresponding $\mathrm{Nb}$ species. However, sulfone was always observed. Benzothiophene was less reactive than methyl phenyl sulfide and dibenzothiophene was not oxidized at all, even at temperatures as high as $70^{\circ} \mathrm{C} .{ }^{118}$

Interestingly, a cyclodextrin inclusion compound containing a dioxo-vanadium with a biphenyl-4-carboxylic acid salicylidene hydrazide ligand has been tested as a catalyst for the oxidation of phenyl methyl sulfide. ${ }^{119}$ Unfortunately, the catalytic activity of the inclusion compound is not very exciting and almost no e.e. was found.

A similar class of hydrazide ligands has been used to prepare some $\mathrm{Mo}(\mathrm{VI})$ dioxo derivatives, which have been proved to be efficient catalysts for the oxidation of sulfides to sulfoxides with $\mathrm{H}_{2} \mathrm{O}_{2} .{ }^{120}$

Also, Mo catalysis in the oxidation of aromatic sulfides is receiving great attention, for its possible application in the oxidative desulfurization of gasoline. ${ }^{121}$

Mono and diperoxo molybdenum complexes, 63 and 75, containing 8-quinolinol as a ligand, have been used in the oxidations of sulfides with $\mathrm{H}_{2} \mathrm{O}_{2}{ }^{70}$ The reaction is catalytic, reaching TON of about 500 . Due to the high reactivity of the peroxo molybdenum species, it is not unexpected that the unselective formation of both sulfoxides and sulfones is observed with aliphatic and aromatic substrates.

A cyclopentadienyl molybdenum acetylide derivative (Fig. 5) has been effectively used in the oxidation of aromatic amines to nitroso derivatives (with substrate conversion $>95 \%$ and selectivity toward nitroso derivatives from 75 to $99 \%$ ). ${ }^{122}$ In this reaction, the presence of a co-solvent was obviously necessary. Increasing the temperature significantly lowered the selectivity. The electron withdrawing, as well as electron-donating, groups are tolerated in the oxidation of aromatic amines.

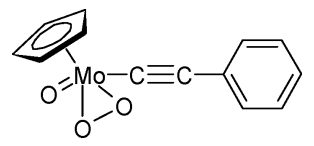

Fig. $5 \mathrm{Mo}(\mathrm{vI})$ acetylide catalyst. 


\section{Oxidation of alcohols}

The selective oxidation of an alcoholic function is an interesting process, which can be performed also with metal peroxides. Homogeneous procedures, as well as two-phase systems, were proposed in the past. ${ }^{3,8}$ The in situ prepared oxo diperoxo vanadate has been proposed as a nucleophile and an oxidant in the oxidation of benzyl alcohol or benzyl halides to the corresponding carbonyl compounds. ${ }^{123}$ Several different aromatic and aliphatic substrates have been tested and high yields, up to $90 \%$, of the aldehydes or ketones have been detected. In the case of the oxidation of primary and secondary benzyl bromides or chlorides, the reaction has been carried out in water in the presence of a phase transfer agent (i.e. Aliquat 336). The reaction mechanism proposed for such a reaction is questionable, considering that acid catalysis is required and it is likely that the protonation of the anionic peroxides occurs before the protonation of the substrate.

A larger number of examples are present in the recent literature concerning the oxidation of alcohols in the presence of Mo catalysts. An effective procedure is based on the use of Mo complexes 63 and 75 , which, in the presence of hydrogen peroxide, catalyse the selective oxidation of several primary and secondary alcohols to the corresponding carbonyl compounds. TONs higher than 800 have been reported. Interestingly, the oxidation of methanol to a mixture of formaldehyde and formic acid was obtained. ${ }^{70}$ Such a catalytic system is active also in the oxidation of phenol and amines.

Interesting reports appeared lately reporting solventless alcohol oxidations with $\mathrm{H}_{2} \mathrm{O}_{2}$, catalysed by $\mathrm{Mo}(\mathrm{vI})$ species. In the first example, 1,4-diazabicyclo[2.2.2] octane was used as a ligand. ${ }^{124}$ The reaction mixture is composed of the alcohol and a $30 \%$ aqueous solution of the oxidant. With benzyl alcohol, a 96\% yield of aldehyde was obtained with $98 \%$ selectivity. Several differently substituted primary and secondary alcohols were tested (aromatic, aliphatic, cyclic, and acyclic) and in all cases the yields and selectivity approached $96 \%$ and $99 \%$, respectively. Even more interesting, is the observation that the catalytic phase can be recycled, without activity loss, thus greatly enhancing the synthetic scope and the sustainability of the procedure.

A similar reactivity has been reported for the cyclopentadienyl molybdenum acetylide derivative of Fig. 5. Such a species activates the hydrogen peroxide, forming, in aqueous solution, a Mo peroxo complex, which selectively oxidizes a series of primary alcohols to the corresponding aldehyde without the need for a co-solvent. ${ }^{125}$ Very high conversions of the substrates are obtained, together with a high selectivity toward the aldehyde ( $>90 \%$, TON $\approx 400$ ).

\section{Oxidation of alkenes}

The selective oxidation of alkenes to the corresponding oxiranes is one of the most important and still challenging reactions, even more problematic being the attainment of enantioselective procedure. This is particularly true when the unsubstituted double bonds are considered.

Several research groups, in the past, reported effective and selective metal catalysed processes with peroxides. In particular, in the presence of $\mathrm{d}^{0}$ early transition metals, hydrogen peroxide can be the primary oxidant, thus extremely increasing the sustainability of the reaction. A general critical collection of such procedures appeared in the Patai series. ${ }^{1}$ To note, several examples of metal peroxides lead to the conversion of the substrate and a selectivity toward epoxides of higher than $90 \%$, so the exploitation of new catalytic systems is actually even more challenging.

Limiting our attention to $\mathrm{V}$ and Mo catalysis, the scope of this review, in recent years there have been almost no reports on the use of isolated peroxo complexes. This is clearly to be expected, considering that the catalytic processes that use cheap and "green" primary oxidants, are much more interesting from all points of view. However, in several cases it is observed that the epoxidation reaction with hydrogen peroxide in the presence of $\mathrm{V}$ or Mo is much less effective with respect to the reaction performed with alkyl hydroperoxides, in particular with TBHP. Nice recent examples of this reactivity refer to half sandwich Mo cyclopentadienyl complexes $^{126}$ and to a supported dioxo Mo species containing tridentate Schiff bases as ligands. ${ }^{127}$

Another example refers to the epoxidation of cyclohexene in the presence of complex $\mathbf{7 2} .{ }^{76}$ With TBHP as the primary oxidant, significant epoxidation is observed, while in the presence of $\mathrm{H}_{2} \mathrm{O}_{2}$ no reaction occurred. However, the Mo oxo diperoxo derivative is isolated upon the reaction of the dioxo precursor in the presence of $\mathrm{H}_{2} \mathrm{O}_{2}$, while any attempt to isolate it from TBHP failed.

A closely related monoperoxo $\mathrm{Mo}(\mathrm{VI})$ species, $\mathbf{6 0}$, has been found to be active in the isomerisation of allylic alcohols, while no oxidative behaviour was detected. ${ }^{67}$

Table 4 contains highlights, with selected model substrates, of catalytic epoxidation with hydrogen peroxide, in the presence of different $\mathrm{V}$ and Mo precursors.

Interestingly, the reactivity and selectivity obtained with molybdenum catalysts are generally much higher than those obtained with vanadium. This observation is in line with the common knowledge that molybdenum peroxo species are better electrophilic oxidants, with respect to their vanadium containing counterparts. Furthermore, it is known that metal catalysed hydrogen peroxide decomposition is much more efficient when vanadium is used, particularly if radical processes take place. ${ }^{99}$

It is noteworthy that some work has been dedicated to the search for new reaction media for catalytic oxidations with $\mathrm{H}_{2} \mathrm{O}_{2}$, in order to obtain even more sustainable processes. In Table 4 , an example is shown related to a reaction with a diperoxo molybdenum in bmimPF $_{6},{ }^{81}$ an ionic liquid that is often used as an alternative to volatile molecular solvents. ${ }^{131}$

Also, complex $\mathbf{7 5}$ has been used in ILs to epoxidize, with $\mathrm{H}_{2} \mathrm{O}_{2}$, a technical mixture of methyl oleate and methyl linoleate in basic conditions. The reaction analysed is significant in view of the utilization of renewable resources. However, the results reported in the presence of the catalyst, the very high conversion of substrates $(>90 \%)$ with an almost total selectivity towards epoxide, appear to be comparable to those obtained in the presence of hydrogen peroxide and carbonate only. ${ }^{132}$

The use of ILs is now quite well established in metal catalysed oxidation reactions, ${ }^{133}$ as well as in many other metal catalysed processes. ${ }^{131}$ In several cases, more selective and faster processes have been obtained, in comparison with similar reactions carried out in molecular solvents. ILs are also useful when microwave heating is used. ${ }^{134}$

The utilization of new reaction media, ILs or supercritical $\mathrm{CO}_{2}$, for metal catalysed oxidations will probably be further explored in the future, with the scope of realizing a more appealing procedure. 
Table 4 Epoxidation reactions with hydrogen peroxide in the presence of selected $\mathrm{V}$ and Mo catalysts

\begin{tabular}{|c|c|c|c|c|c|c|c|c|c|c|c|}
\hline \multirow[b]{3}{*}{ Alkene } & \multirow[b]{3}{*}{ Catalyst } & \multirow[b]{3}{*}{ Solvent } & \multirow[b]{3}{*}{$T /{ }^{\circ} \mathrm{C}$} & \multicolumn{2}{|l|}{$\begin{array}{c}\text { cat } \\
\mathrm{H}_{2} \mathrm{O}_{2}\end{array}$} & & & & & & \multirow[b]{3}{*}{ Ref } \\
\hline & & & & \multirow[b]{2}{*}{ Reaction time } & \multirow[b]{2}{*}{$\%$ conv. } & \multicolumn{5}{|c|}{ Selectivity, $\%$ (yield, $\%$ ) } & \\
\hline & & & & & & epoxide & 1,2-diol & aldehyde & ketone & acid & \\
\hline & $\mathrm{VO}(\operatorname{tmbmz})_{2}{ }^{a}$ & $\mathrm{MeCN}$ & 80 & $6 \mathrm{~h}$ & 64.0 & 2.4 & 84.7 & & 12.4 & & 128 \\
\hline & PS- VO(tmbmz $)_{2}^{a, b}$ & $\mathrm{MeCN}$ & 80 & $6 \mathrm{~h}$ & 86.0 & 3.2 & 81.3 & & 14.8 & & 128 \\
\hline & $\mathrm{MoO}_{2}(\mathrm{tmbmz})_{2}{ }^{a}$ & $\mathrm{MeCN}$ & 80 & $6 \mathrm{~h}$ & 55.0 & 2.2 & 85.7 & & 11.1 & & 128 \\
\hline & PS- $\mathrm{MoO}_{2}(\mathrm{tmbmz})_{2}{ }^{a, b}$ & $\mathrm{MeCN}$ & 80 & $6 \mathrm{~h}$ & 66.0 & 2.3 & 83.4 & & 13.2 & & 128 \\
\hline & {$\left[\mathrm{MoO}\left(\mathrm{O}_{2}\right)_{2}\left(4,4^{\prime} \text {-bipy }\right)\right]_{\mathrm{n}}{ }^{c}, \mathbf{7 6}$} & $\mathrm{CH}_{2} \mathrm{Cl}_{2}$ & $25-40$ & $4-6 \mathrm{~h}$ & $85-90$ & $>99$ & & & & & 77 \\
\hline & $\mathrm{MoO}\left(\mathrm{O}_{2}\right)_{2}(4-\mathrm{MepyO})_{2}{ }^{d}, \mathbf{8 2}$ & $\operatorname{bmimPF}_{6}{ }^{e}$ & 60 & $18 \mathrm{~h}$ & 73 & $>99(73)$ & & & & & 81 \\
\hline & $\mathrm{MoCl}_{2}(\mathrm{O})_{2}\left(\mathrm{OPMePh}_{2}\right)_{2}^{f}$ & $\begin{array}{l}\mathrm{MeCN} \\
\mathrm{EtOH}\end{array}$ & $\begin{array}{l}55 \\
70\end{array}$ & $\begin{array}{l}24 \mathrm{~h} \\
6 \mathrm{~h}\end{array}$ & $\begin{array}{l}35.0 \\
43.0\end{array}$ & $\begin{array}{l}>99 \\
>99\end{array}$ & & & & & $\begin{array}{l}68 \\
68\end{array}$ \\
\hline & $\mathrm{MoCl}_{2}\left(\mathrm{O}_{2}\right)_{2}\left(\mathrm{dppmO}_{2}\right)^{g}$ & $\mathrm{EtOH}$ & 70 & $6 \mathrm{~h}$ & 26.0 & $>99$ & & & & & 68 \\
\hline & {$\left[\mathrm{MoO}\left(\mathrm{O}_{2}\right)_{2}\left(4,4^{\prime} \text {-bipy }\right)\right]_{\mathrm{n}}{ }^{c}, 76$} & $\mathrm{CH}_{2} \mathrm{Cl}_{2}$ & 25 & $6 \mathrm{~h}$ & 40 & $>99$ & & & & & 77 \\
\hline & $\mathrm{MoO}\left(\mathrm{O}_{2}\right)_{2}(4-\mathrm{MepyO})_{2}{ }^{d}, \mathbf{8 2}$ & $\operatorname{bmimPF}_{6}{ }^{e}$ & 60 & $18 \mathrm{~h}$ & $>90$ & $>90$ & & & & & 81 \\
\hline & $\mathrm{VO}(\mathrm{tmbmz})_{2}{ }^{a}$ & $\mathrm{MeCN}$ & 80 & $6 \mathrm{~h}$ & 65.0 & 3.6 & 28.6 & 66.3 & & & 128 \\
\hline & PS- VO(tmbmz $)_{2}^{a, b}$ & $\mathrm{MeCN}$ & 80 & $6 \mathrm{~h}$ & 81.0 & 4.9 & 29.4 & 62.6 & & & 128 \\
\hline & $\mathrm{MoO}_{2}(\mathrm{tmbmz})_{2}{ }^{a}$ & $\mathrm{MeCN}$ & 80 & $6 \mathrm{~h}$ & 49.0 & 3.0 & 27.0 & 68.8 & & & 128 \\
\hline & PS- $\mathrm{MoO}_{2}(\mathrm{tmbmz})_{2}{ }^{a, b}$ & $\mathrm{MeCN}$ & 80 & $6 \mathrm{~h}$ & 68.0 & 3.1 & 29.5 & 66.0 & & & 128 \\
\hline & $\mathrm{MoO}\left(\mathrm{O}_{2}\right)_{2}(4-\mathrm{MepyO})_{2}{ }^{d}, \mathbf{8 2}$ & $\operatorname{bmim} \mathrm{PF}_{6}{ }^{e}$ & 60 & $18 \mathrm{~h}$ & 57.0 & $>99(10)$ & & & & & 81 \\
\hline & $\mathrm{VO}\left(\mathrm{Acpyr}^{\mathrm{I}}\right)_{2}{ }^{h}$ & $\mathrm{MeCN}$ & 25 & $18 \mathrm{~h}$ & 88.0 & & $15(13)$ & $62(55)$ & & $23(20)$ & 129 \\
\hline & $\mathrm{VO}\left(\mathrm{Acpyr}^{\mathrm{II}}\right)_{2}{ }^{i}$ & $\mathrm{MeCN}$ & 25 & $18 \mathrm{~h}$ & 48.8 & $6(3)$ & $4(2)$ & $86(41)$ & & $4(2)$ & 129 \\
\hline & $\mathrm{VO}\left(\mathrm{Acpyr}^{\mathrm{IV}}\right)_{2}^{j}$ & $\mathrm{MeCN}$ & 25 & $18 \mathrm{~h}$ & 35.0 & & & $100(76)$ & & & 129 \\
\hline & $\mathrm{VO}\left(\mathrm{Acpyr}^{\mathrm{V}}\right)_{2}{ }^{k}$ & $\mathrm{MeCN}$ & 25 & $18 \mathrm{~h}$ & 84.0 & & $11(9)$ & $70(59)$ & & $19(16)$ & 129 \\
\hline & $\mathrm{VO}\left(\mathrm{Acpyr}^{\mathrm{VI}}\right)_{2}{ }^{l}$ & $\mathrm{MeCN}$ & 25 & $18 \mathrm{~h}$ & 90.0 & & $12(11)$ & $67(60)$ & & $21(19)$ & 129 \\
\hline & $\mathrm{VO}\left(\mathrm{Acpyr}^{\mathrm{VII}}\right)_{2}{ }^{m}$ & $\mathrm{MeCN}$ & 25 & $18 \mathrm{~h}$ & 85.0 & & $6(5)$ & $71(60)$ & & $23(20)$ & 129 \\
\hline & $\mathrm{MS}-\mathrm{MoO}\left(\mathrm{O}_{2}\right)_{2}(\mathrm{QOH})_{2}{ }^{n}$ & $\mathrm{MeCN}$ & 25 & $20 \mathrm{~h}$ & 98.0 & 74 & & 24 & & & 130 \\
\hline & $\mathrm{MS}-\mathrm{MoO}\left(\mathrm{O}_{2}\right)_{2}(\mathrm{QO})^{n}$ & $\mathrm{MeCN}$ & 25 & $20 \mathrm{~h}$ & 96.0 & 76 & & 20 & & & 130 \\
\hline
\end{tabular}

${ }^{a}$ tmbmz $=2$-thiomethylbenzimidazole. ${ }^{b} \mathrm{PS}=$ polymer supported. ${ }^{c}$ heterogeneous; $4,4^{\prime}$-bipy $=4,4^{\prime}$-bipyridyl. ${ }^{d}$ 4-Mepy $=4$-methylpyridine; $\mathrm{H}_{2} \mathrm{O}_{2} /$ urea (UHP) used as the oxidant. ${ }^{e}$ bmim $=$ butylmethylimidazolium cation. ${ }^{f}$ with $\mathrm{H}_{2} \mathrm{O}_{2}$, it forms complex $72 .{ }^{g}$ with $\mathrm{H}_{2} \mathrm{O}_{2}$, it forms complex 73 . ${ }^{h} \mathrm{VO}\left(\mathrm{Acpyr}{ }^{\mathrm{I}}\right)_{2}=1$-phenyl-3-methyl-4-terz-butylacetyl-5-pyrazolone. ${ }^{i} \mathrm{VO}\left(\mathrm{Acpyr}^{\mathrm{II}}\right)_{2}=1$,3-dimethyl-4-acetyl-5-pyrazolone. ${ }^{j} \mathrm{VO}\left(\mathrm{Acpyr} \mathrm{I}^{\mathrm{IV}}\right)_{2}=1,3$-dimethyl4-(1-naphthoyl)-5-pyrazolone. ${ }^{k} \mathrm{VO}\left(\mathrm{Acpyr}^{\mathrm{V}}\right)_{2}=1$-phenyl-3-methyl-4-benzoyl-5-pyrazolone. ${ }^{\prime} \mathrm{VO}\left(\mathrm{Acpyr}^{\mathrm{VI}}\right)_{2}=1$-phenyl-3-methyl-4-trifluoroacetyl-5pyrazolone. ${ }^{m} \mathrm{VO}\left(\mathrm{Acpyr}^{\mathrm{VII}}\right)_{2}=1$-(2-pyridyl)-3-methyl-4-trifluoroacetyl-5-pyrazolone. ${ }^{n} \mathrm{MS}=$ mesoporous silica; $\mathrm{QOH}=8$-quinolinol.

The cyclopentadienyl molybdenum acetylide ${ }^{122}$ derivative is an efficient catalyst in performing the cis-dihydroxylation of olefins in the presence of hydrogen peroxide. ${ }^{135}$ By using cyclohexene, an interesting conversion of the substrate $(95 \%)$ and a high selectivity in the formation of the diol was obtained, using $t-\mathrm{BuOH}$ as the solvent, see Scheme 13. Up to 5 catalytic cycles were obtained, either adding $\mathrm{H}_{2} \mathrm{O}_{2}$ stepwise or recycling the catalyst after isolation from the reaction mixture.

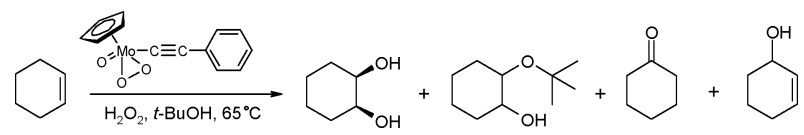

Scheme 13 The cis-dihydroxylation of cyclohexene.

\section{Oxidation of alkanes}

One of the most attractive transformations of organic substrates is the selective oxidation of alkanes in mild conditions. Certainly, the replacement of the nowadays-used harsh industrial oxidation procedures would have a great impact. Truly sustainable and effective processes should make use of dioxygen as the primary oxidant, without the need for a sacrificial reductant and some procedures have been proposed during the years, based on diverse metals and also on polyoxometallates. ${ }^{136}$ The reaction is likely to involve radical intermediates and, therefore, with the metals we are discussing here, the use of the reduced form of the catalyst is necessary (i.e. V(IV) complexes). Just as an example, the simple $\mathrm{VO}(\mathrm{acac})_{2}$ has been used in the oxidation of adamantane to 1and 2-adamantol and 2-adamantanone with dioxygen in acid conditions. ${ }^{137}$ Evidence on the occurrence of the peroxo vanadium species has been obtained.

The situation is different if we concentrate on the $\mathrm{V}(\mathrm{v}) / \mathrm{H}_{2} \mathrm{O}_{2}$ systems. In this respect, a breakthrough was obtained, more than twenty-five years ago, by Mimoun, with the synthesis of $\mathrm{VO}\left(\mathrm{O}_{2}\right)$ pic (pic = picolinate), a species that is very active in the hydroxylation of alkanes and aromatics. ${ }^{138}$ Subsequently, with a closely related species, Shul'pin reported, in numerous different papers, the oxidation of many diverse hydrocarbons. Just as a recent example, the bis(maltolato) vanadium oxo complex, in the presence of pyrazine-2-carboxylic acid, was used in the oxidation, with $\mathrm{H}_{2} \mathrm{O}_{2}$, of cyclohexane to cyclohexyl hydroperoxide and benzene to phenol. ${ }^{139}$ Other substrates were also examined, with the aim of determining the selectivity parameters. There were quite low values observed in all the experimental conditions used. To note, when the maltolato precursor was heterogenized on modified silica gel, the catalytic activity was much lower and the selectivity was modified. 
Another interesting example refers to the aminebis(phenolate) oxo vanadium(v) complex, Fig. 6. This species, which resembles, as many others do, the VHPOs enzymes active site, is effective in the catalytic oxidation of various methylbenzenes to the corresponding acids and hydroxymethyl benzoic acids.

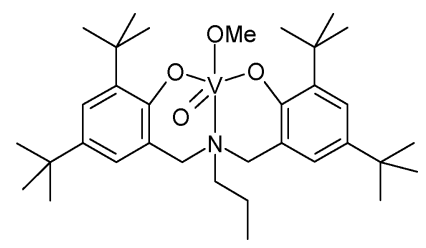

Fig. 6 Oxo vanadium catalyst for the oxidation of methyl benzenes.

The TONs obtained are higher than $130 .{ }^{140}$ The authors propose the intermediate formation of a hydroxo-hydroperoxo species as the active oxidant.

In 2008 , the catalytic activity of the two oxo vanadium(v) complexes, containing, respectively, salicylhydroximate and 5chloro salicylhydroximate ligands, were tested in the hydroxylation of aromatic and aliphatic substrates. ${ }^{141}$ In the presence of fivefold excesses of hydrogen peroxide, the high conversion of the substrates, with TON up to 360 , was achieved. Lower conversions and selectivity were observed with linear alkanes, in comparison with those of cyclohexane, this substrate being the most oxidizable one. Interesting yields and selectivity were observed also with several aromatic substrates.

\section{Conclusions}

In this in no way comprehensive review, we hopefully have offered to the scientists interested in catalytic oxidations, an outline, clearly limited to the $\mathrm{V}(\mathrm{v})$ and $\mathrm{Mo}(\mathrm{VI})$ species, on the recent activity in this field. In doing so, it has been realized that, even though many features of isolated peroxo complexes are elucidated, in many examples the catalysis with them is scarcely explored.

As a personal note, we would like to underline that the research in metal catalyzed oxidation with peroxides will have an even greater future, if and when more efficient and sustainable protocols are established..$^{142}$ The adherence to the principles of green chemistry is already assured by the fact that these reactions employ hydrogen peroxide, one of the most sustainable oxidants and a catalyst, which, in several instances, can be reused in subsequent cycles without losing activity. ${ }^{143}$ Therefore, much of the work should be devoted firstly to increasing the performance of the catalysts, in terms both of turnover numbers and turnover frequency and secondly, but not with less importance, to the reduction of the environmental impact due to the use of large amounts of harmful volatile organic solvents.

\section{References}

1 V. Conte and O. Bortolini, Transition Metal Peroxides, Synthesis and Role in Oxidation Reactions. In "The Chemistry of Peroxides" Vol. 2, Part 1, Wiley, 2006, 1053, ISBN: 0-470-86274-2 and references cited therein.

2 Peroxide Chemistry. Mechanistic and Preparative Aspects of Oxygen Transfer, Ed. W. Adam, Wiley-VCH, Verlag GmbH, Weinheim, 2000.

3 V. Conte, F. Di Furia and G. Modena, in Organic Peroxides, Ed. W. Ando, John Wiley \& Sons Ltd,1992, Ch. 11.2, 559-598 and refs. cited therein.
4 I. W. C. E. Arends and R. A. Sheldon, Top. Catal., 2002, 19, 133141.

5 See as an example N. A. Milas and L. S. Malorey, J. Am. Chem. Soc., 1940, 62, 1841-1843.

6 W. F. Brill and N. Indictor, J. Org. Chem., 1964, 29, 710-713; N. Indictor and W. F. Brill, J. Org. Chem., 1965, 30, 2074-2075.

7 T. Katsuki and K. B. Sharpless, J. Am. Chem. Soc., 1980, 102, 5974 5976.

8 R. A. Sheldon and J. K. Kochi, Metal Catalyzed Oxidations of Organic Compounds, Academic Press, New York, 1981; H. Mimoun, in The Chemistry of Functional Groups. Peroxides, Ed. S. Patai, 1983, Ch. 15, 463-482.

9 L. Vaska, Acc. Chem. Res., 1976, 9, 175-183.

10 W. Adam, W. Malisch, K. J. Roschmann, C. R. Saha-Möller and W. A. Schenk, J. Organomet. Chem., 2002, 661, 3-16.

11 M. H. Dickman and M. T. Pope, Chem. Rev., 1994, 94, 569-584 and references cited therein.

12 See, as an example, N. J. Campbel, A. C. Dengel and W. P. Griffith, Polyhedron, 1989, 8, 1379-1386.

13 P. Schwendt and M. Sivák, in Vanadium Compounds: Chemistry, Biochemistry and Therapeutic Applications, ACS series book 711, ed. D. C. Crans and A. Tracey, American Chemical Society, Whashington D.C., 1998, Ch. 8.

14 M. Bhattacharjee, S. K. Chettri, M. K. Chaudhuri, N. S. Islam and S. R. Barman, J. Mol. Catal., 1993, 78, 143-149.

15 M. Bonchio, O. Bortolini, V. Conte and S. Moro, Eur. J. Inorg. Chem., 2001, 2913-2919 and references cited therein.

16 V. Conte, F. Di Furia and S. Moro, J. Phys. Org. Chem., 1996, 9, 329-336.

17 Catalytic Oxidations with Hydrogen Peroxide as Oxidant, Ed. G. Strukul, Kluwer Academic Publishers, Dordrecht, 1992.

18 A. Butler, M. J. Clague and G. E. Meister, Chem. Rev., 1994, 94, 625-638.

19 O. Bortolini and V. Conte, J. Inorg. Biochem., 2005, 99, 1549-1557.

20 ACS Symposium Series 974: Vanadium: the Versatile Metal, ed. K. Kustin, J. Costa Pessoa and D. C. Crans, American Chemical Society, Whashington D.C., 2007.

21 V. S. Sergienko, Crystallogr. Rep., 2004, 49, 401-426.

22 V. S. Sergienko, Crystallogr. Rep., 2008, 53, 18-46.

23 H. Mimoun, I. Seree de Roche and L. Sajus, Tetrahedron, 1970, 26, $37-50$.

24 N. Vuletic and C. Djordjevic, J. Chem. Soc., Dalton Trans., 1973, $1137-1141$.

25 H. Arzoumanian, J.-F. Petrignani, M. Pierot, F. Ridouane and J. Sanchez, Inorg. Chem., 1988, 27, 3377-3381; J. Tachibana and T. Imamura, Chem. Lett., 1990, 2085-2088.

26 C. R. Waidmann, A. G. Di Pasquale and J. M. Mayer, Inorg. Chem., 2010, 49, 2383-2391.

27 J. Tatiersky, S. Pacigová, M. Sivák and P. Schwendt, J. Arg. Chem. Soc., 2009, 97, 181-198.

28 D. C. Crans, A. D. Keramidas, H. Hoover-Litty, O. P. Anderson, M. M. Miller, L. M. Lemoine, S. Pleasic-Williams, M. Vandenberg, A. J. Rossomando and L. J. Sweet, J. Am. Chem. Soc., 1997, 119, $5447-5448$.

29 M. Ahmed, P. Schwendt, M. Sivák and J. Marek, Transition Met. Chem., 2004, 29, 675-680.

30 M. Casný and D. Rehder, Dalton Trans., 2004, 839-846 and references. cited therein.

31 M. Mad'arova, M. Sivák, L. Kuchta, J. Marek and J. Benko, Dalton Trans., 2004, 3313-3320.

32 M. Kaliva, C. P. Raptopoulou, A. Terzis and A. Salifoglou, Inorg. Chem., 2004, 43, 2895-2905.

33 M. Kaliva, E. Kyriakakis, C. Gabriel, C. P. Raptopoulou, A. Terzis and A. Salifoglou, Inorg. Chim. Acta, 2006, 359, 4535-4548.

34 M. Kaliva, C. Gabriel, C. P. Raptopoulou, A. Terzis and A. Salifoglou, Inorg. Chim. Acta, 2008, 361, 2631-2640.

35 S. Pacigová, R. Gyepes, J. Tatiersky and M. Sivák, Dalton Trans., 2008, 121-130.

36 J. Tatiersky, P. Schwendt, M. Sivák and J. Marek, Dalton Trans., 2005, 2305-2311.

37 Y. Tajika, K. Tsuge and Y. Sasaki, Dalton Trans., 2005, 1438-1447.

38 P. Schwendt, M. Ahmed and J. Marek, Inorg. Chim. Acta, 2005, 358, 3572-3580.

39 Y. Xing, Y. Zhang, Z. Sun, L. Ye, Y. Xu, M. Ge, B. Zhang and S. Niu, J. Inorg. Biochem., 2007, 101, 36-43. 
40 S. Nica, A. Pohlmann and W. Plass, Eur. J. Inorg. Chem., 2005, 20322036.

41 J. Chrappová, P. Schwendt, D. Dudášová, J. Tatiersky and J. Marek, Polyhedron, 2008, 27, 641-647.

42 S. Sarmah, D. Kalita, P. Hazarika, R. Borah and N. S. Islam, Polyhedron, 2004, 23, 1097-1107.

43 J. Chrappová, P. Schwendt and J. Marek, J. Fluorine Chem., 2005, 126, 1297-1302.

44 X. Yu, J. Zhang, S. Cai, P. Yi and Z. Chen, Spectrochim. Acta, Part A, 2009, 72, 965-969.

45 W. Przybylski, R. Gryboś, D. Rehder, M. Ebel, M. Grzywa, W. Łasocha, K. Lewiński and J. T. Szklarzewicz, Polyhedron, 2009, 28, 1429-1436.

46 P. Hazarika, S. Sarmah, D. Kalita and N. S. Islam, Transition Met. Chem., 2008, 33, 69-77.

47 J. Chrappová, P. Schwendt, M. Sivák, M. Repiský, V. G. Malkin and J. Marek, Dalton Trans., 2009, 465-473.

48 C. Gabriel, M. Kaliva, J. Venetis, P. Baran, I. Rodriguez-Escudero, G. Voyiatzis, M. Zervou and A. Salifoglou, Inorg. Chem., 2009, 48, 476-487.

49 D. Kalita, S. Sarmah, S. Prasad Das, D. Baishya, A. Patowary, S. Baruah and N. S. Islam, React. Funct. Polym., 2008, 876-898.

50 D. Rehder, M. Časný and R. Grosse, Magn. Reson. Chem., 2004, 42, 745-749.

51 A. González Baró, I. Andersson, L. Pettersson and A. Gorzsás, Dalton Trans., 2008, 1095-1102.

52 A. Gorzsás, I. Andersson and L. Pettersson, J. Inorg. Biochem., 2009, 103, 517-526.

53 X. Yu, S. Cai and Z. Chen, Spectrochim. Acta, Part A, 2004, 60, 391396.

54 B. Zeng, X. Zhu, X. Yu, S. Cai and Z. Chen, Spectrochim. Acta, Part $A, 2008,69,117-122$.

55 C. Gabriel, J. Venetis, M. Kaliva, C. P. Raptopoulou, A. Terzis, C. Drouza, B. Meier, G. Voyatzis, C. Potamitis and A. Salifoglou, J. Inorg. Biochem., 2009, 103, 503-516.

56 M. Bühl, in ACS Symposium Series 974: Vanadium: the Versatile Metal, ed. K. Kustin, J. Costa Pessoa and D. C. Crans, American Chemical Society, Washington D.C., 2007, Ch. 22, 312-322.

57 M. Bühl, J. Comput. Chem., 1999, 20, 1254-1261.

58 V. Conte, F. Di Furia and S. Moro, J. Mol. Catal. A: Chem., 1995, 104, 159-169.

59 H. Schmidt, I. Andersson, D. Rehder and L. Pettersson, Chem.Eur. J., 2001, 7, 251-257.

60 K. H. Thompson, J. H. McNeill and C. Orvig, Chem. Rev., 1999, 99, 2561-2567.

61 D. C. Crans, J. J. Smee, E. Gaidamauskas and L. Yang, Chem. Rev., 2004, 104, 849-902.

62 I. Bányai, V. Conte, L. Pettersson and A. Silvagni, Eur. J. Inorg. Chem., 2008, 5373-5381.

63 M. Aureliano, T. Tiago, R. M. C. Gândara, A. Sousa, A. Moderno, M. Kaliva, A. Salifoglou, R. O. Duarte and J. J. G. Moura, J. Inorg. Biochem., 2005, 99, 2355-2361.

64 Q.-L. Zeng, W.-Z. Chen and Y.-F. Zhao, Int. J. Mass Spectrom., 2007, 262, 161-167.

65 O. Bortolini and V. Conte, Mass Spectrom. Rev., 2006, 25, 724-740.

66 G. Lyashenko, G. Saischeck, A. Pal, R. Herbst-Irmer and N. C. Mösch-Zanetti, Chem. Commun., 2007, 701-703.

67 G. Wang, A. Jimtaisong and R. L. Luck, Inorg. Chim. Acta, 2005, 358, 933-940.

68 A. Jimtaisong and R. L. Luck, Inorg. Chem., 2006, 45, 10391-10402.

69 D. Bayot, B. Tinant and M. Devillers, Inorg. Chim. Acta, 2004, 357, 809-816.

70 S. K. Maiti, S. Banerjee, A. K. Mukherjee, K. M. Abdul Malik and R. Bhattacharyya, New J. Chem., 2005, 29, 554-563.

71 A. Jimtaisong and R. L. Luck, J. Cluster Sci., 2005, 16, 167-184.

72 H. Vrubel, M. Hörner, E. dos Reis Crespan, S. Nakagaki and F. S. Nunes, Z. Anorg. Allg. Chem., 2008, 634, 1839-1841.

73 A. M. Al-Ajlouni, D. Veljanovski, A. Capapé, J. Zhao, E. Herdtweck, M. J. Calhorda and F. E. Kühn, Organometallics, 2009, 28, 639-645.

74 X.-Y. Shi, J.-F. Wei, X.-R. Zhang and J. Cao, Acta Crystallogr., Sect. E: Struct. Rep. Online, 2007, 63, m227-m229.

75 Z.-H. Zhou, S.-Y. Hou and H.-L. Wan, Dalton Trans., 2004, 13931399.

76 G. Wang, G. Chen, R. L. Luck, Z. Wang, Z. Mu, D. G. Evans and X. Duan, Inorg. Chim. Acta, 2004, 357, 3223-3229.
77 M. Afsharpour, A. R. Mahjoub and M. M. Amim, Appl. Catal., A, 2007, 327, 205-210.

78 L. Salles, J.-Y. Piquemal, Y. Maha, M. Gentil, P. Herson and J.-M. Brégeault, Polyhedron, 2007, 26, 4786-4792.

79 H.-B. Lin, C.-Y. Chen, X.-L. Liao, T.-R. Lin and Z.-H. Zhou, Synth. React. Inorg. Met.-Org. Nano-Met. Chem., 2006, 36, 411-414.

80 M. Grzywa, W. Nitek and W. Łasocha, J. Mol. Struct., 2008, 888, 318-326.

81 M. Herbert, F. Montilla, R. Moyano, A. Pastor, E. Álvarez and A. Galindo, Polyhedron, 2009, 28, 3929-3924.

82 M. Sharma, M. Saleem, M. S. Pathania, H. N. Sheikh and B. L. Kalsotra, Chin. J. Chem., 2009, 27, 311-316.

83 M. Grzywa, W. Nitek and W. Łasocha, J. Mol. Struct., 2007, 828, $111-115$.

84 M. Grzywa, W. Lasocha and D. Rutkowska-Żbik, J. Solid State Chem., 2009, 182, 973-982.

85 F. E. Kühn, A. M. Santos and M. Abrantes, Chem. Rev., 2006, 106, $2455-2475$.

86 E. P. Talsi, O. V. Klimov and K. I. Zamaraev, J. Mol. Catal., 1993, 83, 329-346.

87 D. Kalita, R. C. Deka and N. S. Islam, Inorg. Chem. Commun., 2007, 10, 45-48.

88 P. Adão, J. Costa Pessoa, R. T. Henriques, M. L. Kuznetsov, F. Avecilla, M. R. Maurya, U. Kumar and I. Correia, Inorg. Chem., 2009, 48, 3542-3561.

89 P. Adão, M. R. Maurya, U. Kumar, F. Avecilla, R. T. Henriques, M. L. Kuznetsov, J. Costa Pessoa and I. Correia, Pure Appl. Chem., 2009, 81, 1279-1296.

90 M. L. Kuznetsov and J. Costa Pessoa, Dalton Trans., 2009, 54605468.

91 A. A. Markov, S. P. Dolin, N. I. Moiseeva, A. E. Gekhman and I. I. Moiseev, Kinet. Catal., 2009, 50, 656-665.

92 A. A. Markov, S. P. Dolin, N. I. Moiseeva, A. E. Gekhman and I. I. Moiseev, Mendeleev Commun., 2009, 19, 175-181.

93 A. A. Markov, S. P. Dolin, N. I. Moiseeva, A. E. Gekhman and I. I. Moiseev, Dokl. Phys. Chem., 2010, 431, 82-86.

94 A. F. Shestakov and N. S. Emel'yanova, Mendeleev Commun., 2004, 14, 117-118.

95 M. Bühl, R. Schurhammer and P. Imhof, J. Am. Chem. Soc., 2004, 126, 3310-3320.

96 A. Shiga and Y. Kurusu, J. Mol. Catal. A: Chem., 2008, 291, 3848.

97 F. R. Sensato, R. Custodio, E. Longo, V. S. Safont and J. Andrés, Eur. J. Org. Chem., 2005, 2406-2415.

98 P. J. Costa, M. J. Calhorda and F. E. Kühn, Organometallics, 2010, 29, 303-311.

99 V. Conte and B. Floris, Inorg. Chim. Acta, 2010, 363, 1935-1946 and references cited therein.

100 See as an example M. V. Kirillova, M. L. Kuznetsov, V. B. Romakh, L. S. Shul'pina, J. J. R. Fraústo da Silva, A. J. L. Pombeiro and G. B. Shul'pin, J. Catal., 2009, 267, 140-167.

101 J. M. Khurana, A. Agrawal and S. Kumar, J. Brasil. Chem. Soc., 2009, 20, 1265-1261.

102 L. Csányi, J. Mol. Catal. A: Chem., 2010, 322, 1-6.

103 G. J. Colpas, B. J. Hamstra, J. W. Kampf and V. L. Pecoraro, J. Am. Chem. Soc., 1994, 116, 3627-3628.

104 C. J. Schneider, J. E. Penner-Hahn and V. L. Pecoraro, J. Am. Chem. Soc., 2008, 130, 2712-2713.

105 C. J. Schneider, G. Zampella, C. Greco, V. L. Pecoraro and L. De Gioia, Eur. J. Inorg. Chem., 2007, 515-523.

106 G. Zampella, P. Fantucci, V. L. Pecoraro and L. De Gioia, J. Am. Chem. Soc., 2005, 127, 953-960.

107 G. Zampella, P. Fantucci, V. L. Pecoraro and L. De Gioia, Inorg. Chem., 2006, 45, 7133-7143.

108 G. Zampella, J. Y. Kravitz, C. E. Webster, P. Fantucci, M. B. Hall, H. A. Carlson, V. L. Pecoraro and L. De Gioia, Inorg. Chem., 2004, 43, 4127-4136.

109 Y. Tajika, K. Tsuge and Y. Sasaki, Chem. Lett., 2006, 35, 1180-1181.

110 C. R. Waidmann, A. Di Pasquale and J. M. Mayer, Inorg. Chem., 2010, 49, 2383-2391.

111 A. G. J. Ligtenbarg, R. Hage and B. L. Feringa, Coord. Chem. Rev., 2003, 237, 89-101.

112 A. Butler, Coord. Chem. Rev., 1999, 187, 17-35.

113 M. Mba, M. Pontini, S. Lovat, C. Zonta, G. Bernardinelli, P. E. Kündig and G. Licini, Inorg. Chem., 2008, 47, 8616-8618. 
114 T. L. Fernández, E. T. Souza, L. C. Visentin, J. V. Santos, A. S. Mangrich, R. B. Faria, O. A. C. Antunes and M. Scarpellini, J. Inorg. Biochem., 2009, 103, 474-479.

115 C. Bolm, Coord. Chem. Rev., 2003, 237, 245-256.

116 See as an example C. Witeke, P. Wu, G. Zampella, L. De Gioia, G. Licini and D. Rehder, Inorg. Chem., 2007, 46, 196-207.

117 S.-H. Hsieh, Y.-P. Kuo and H.-M. Gau, Dalton Trans., 2007, 97-106.

118 F. V. Tkhai, A. V. Tarakanova, O. V. Kostyuchenko, B. N. Tarasevich, N. S. Kulikov and A. V. Anisimov, Theor. Found. Chem. Eng., 2008, 42, 537-543.

119 I. Lippold, K. Vlay, H. Görls and W. Plass, J. Inorg. Biochem., 2009, 103, 480-486.

120 R. Debel, A. Buchholz and W. Plass, Z. Anorg. Allg. Chem., 2008, 634, 2291-2298.

121 See a san example: M. Ciclosi, C. Dinoi, L. Gonsalvi, M. Peruzzini, E. Monoury and R. Poli, Organometallics, 2008, 27, 2281-2286.

122 A. V. Biradar, T. V. Kotbagi, M. K. Dongare and S. B. Umbarkar, Tetrahedron Lett., 2008, 49, 3616-3619.

123 C. Li, P. Zheng, J. Li, H. Zhang, Y. Cui, Q. Shao, X. Ji, J. Zhang, P. Zhao and Y. Xu, Angew. Chem., Int. Ed., 2003, 42, 5063-5066.

124 Y. Luan, G. Wang, R. L. Luck, M. Yang and X. Han, Chem. Lett., 2007, 36, 1236-1237.

125 A. V. Biradar, M. K. Dongare and S. B. Umbarkar, Tetrahedron Lett., 2009, 50, 2885-2888.

126 A. M. Martins, C. C. Romão, M. Abrantes, M. C. Azevedo, J. Cui, A. R. Dias, M. T. Duarte, M. A. Lemos, T. Lourenço and R. Poli, Organometallics, 2005, 24, 2582-2589.

127 Y. Li, X. Fu, B. Gong, X. Zou, X. Tu and J. Chen, J. Mol. Catal. A: Chem., 2010, 322, 55-62.
128 M. R. Maurya, A. Arya, P. Adão and J. Costa Pessoa, Appl. Catal., A, 2008, 351, 239-252.

129 F. Marchetti, C. Pettinari, C. Di Nicola, R. Pettinari, A. Crispini, M. Crucianelli and A. Di Giuseppe, Appl. Catal., A, 2010, 378, 211-220.

130 S. K. Maiti, S. Dinda, M. Nandi, A. Bhaumik and R. Bhattacharyya, J. Mol. Catal. A: Chem., 2008, 287, 135-141.

131 V. I. Parvulescu and C. Hardacre, Chem. Rev., 2007, 107, 2615-2665; H. Oliver-Bourbigou, L. Magna and D. Morvan, Appl. Catal., A, $2010,373,1-56$.

132 S.-F. Cai, L.-S. Wang and C.-L. Fan, Molecules, 2009, 14, 2935-2946.

133 J. Muzart, Adv. Synth. Catal., 2006, 348, 275-295.

134 B. A. Roberts and C. R. Strauss, Acc. Chem. Res., 2005, 38, 653-661.

135 A. V. Biradar, B. R. Sathe, S. B. Umbarkar and M. K. Dongare, J. Mol. Catal. A: Chem., 2008, 285, 111-119.

136 See as an example M. Bonchio, M. Carraro, G. Scorrano and U. Kortz, Adv. Synth. Catal., 2005, 347, 1909-1912.

137 H. Kobayashi and I. Yamanaka, Chem. Lett., 2007, 36, 114-115.

138 H. Mimoun, L. Saussine, E. Daire, M. Postel, J. Fisher and R. Weiss, J. Am. Chem. Soc., 1983, 105, 3101-3110.

139 G. B. Shul'pin, G. S. Mishra, L. S. Shul'pina, T. V. Strelkova and A. J. L. Pombeiro, Catal. Commun., 2007, 8, 1516-1520.

140 D. Maity, J. Marek, W. S. Sheldrick, H. Mayer-Figge and M. Ali, J. Mol. Catal. A: Chem., 2007, 270, 153-159.

141 T. K. Si, S. Chakraborty, A. K. Mukherjee, M. G. B. Drew and R. Bhattacharyya, Polyhedron, 2008, 27, 2233-2242.

142 D. J. C. Constable, P. J. Dunn, J. D. Hayler, G. R. Humphrey, J. L. Leazer, Jr., R. J. Linderman, K. Lorenz, J. Manley, B. A. Pearlman, A. Wells, A. Zaks and T. Y. Zhang, Green Chem., 2007, 9, 411-420.

143 See as an example: R. A. Sheldon, Chem. Commun., 2008, 3352-3365. 